\title{
Development of a Middle Bronze Age (1900-1500 cal BC) house at the site of Százhalombatta-Földvár, Hungary: detecting choice of materials by the means of archaeological thin section soil micromorphology and phytolith analysis
}

\author{
Gabriella Kovács $^{1} \cdot$ Ákos Pető $^{2}$ (D) $\cdot$ Magdolna Vicze $^{1}$ \\ Received: 18 March 2020 / Accepted: 11 September 2020 / Published online: 14 October 2020 \\ (C) The Author(s) 2020
}

\begin{abstract}
Százhalombatta-Földvár Bronze Age tell settlement is one of the most extensively studied sites of Hungary. Interdisciplinary approach is one of the key factors in understanding the past here. Therefore, a range of natural scientific methods are applied, including thin section soil micromorphology and phytolith analysis. The high resolution of these techniques is used to add details that are impossible via traditional archaeological means. In this paper, we aim to look at decision-making in choices of construction materials. A Middle Bronze Age house (ID 3147), belonging to the so-called Vatya Culture, was sampled to investigate the used materials, the building techniques and space use. Earthen floors, clay floor, wall and hearth material are under the microscope for a better understanding of Bronze Age construction and everyday life. Micro fragments are traced to investigate space use and activities inside the house. It is also our intention to further test the conjoint application of the abovementioned methods to add data and encourage work between the experts of the two fields as there is only a handful of such studies available.
\end{abstract}

Keywords Thin section soil micromorphology $\cdot$ Phytolith analysis · Geoarchaeology $\cdot$ Site stratigraphy $\cdot$ Taphonomy $\cdot$ Bronze age $\cdot$ Vatya culture $\cdot$ Carpathian Basin

\section{Introduction}

\section{Archaeological background}

Százhalombatta-Földvár is one of the key sites in recent Bronze Age research in the Carpathian Basin. It is a tell

Electronic supplementary material The online version of this article (https://doi.org/10.1007/s12520-020-01205-z) contains supplementary material, which is available to authorized users.

Ákos Pető

Peto.Akos@szie.hu

Gabriella Kovács

antropologus@yahoo.com

Magdolna Vicze

vicze@matricamuzeum.hu

1 'Matrica' Museum and Archaeological Park, Gesztenyés út 1-3, Százhalombatta 2440, Hungary

2 Institute of Nature Conservation and Landscape Management, Szent István University, Páter Károly u. 1, Gödöllő 2100, Hungary settlement, with proximately 5-m thick cultural layers, that is seated on the high bank of the Danube. The site was first occupied during the Early Bronze Age (from 2300/2200 BC) and was inhabited continuously till the end of the Hungarian Middle Bronze Age (i.e. 1500/1450 BC). Its location has always kept the area in the centre of interest during the Bronze Age, just as well as today for modern research. The settlement is located on a promontory-like plateau some $160 \mathrm{~m}$ above the river, providing an excellent view of upstream, down and also across the river over the flat floodplain on the other side. The modern archaeological research of the site started during the 2 nd half of the twentieth century. The result of that was the identification of SzázhalombattaFöldvár as one of the outstanding fortified settlements of the Hungarian Middle Bronze Age cultural unit called Vatya. The most recent and still ongoing excavation project started in 1998 with the primary aim of understanding Bronze Age social dynamics playing within the daily life and routines of a presumably high-tier settlement with the help of the most recent interdisciplinary developments (Kristiansen 2000; Poroszlai and Vicze 2004a; Sørensen et al. in press; Vicze et al. 2017). The site since then is a centre for evolving new 
methods and supplying data and material for novel research areas.

The Vatya culture chronologically is coeval with the timespan of the Middle Bronze Age (1900/1800-1500/ $1450 \mathrm{BC})$ in Hungary. Their territory geographically is located in the central part of the country encompassing both banks of the Danube. It is a so-called tell-forming society, which means that their settlements have continuous occupation for hundreds of years and their households and activity areas were rebuilt and reconstructed over and over the remains of previous ones. This gives ample opportunity to specifically focus on domestic contexts (Sørensen and Vicze 2013; Vicze et al. 2014) among which constructing, maintaining and rebuilding of houses and features are of primary interest (Sørensen 2010; Kovács 2013; Vicze 2013). Our understanding of Vatya houses is that they are usually 8-10 $\mathrm{m}$ long, 4-5 $\mathrm{m}$ wide and were made of wattle and daub walls seated between posts. The posts were carrying the weight of the slanting roofs composed of reed or thatch on wooden frames. The posts were integrated into the walls with plastering (using clay), thus visually producing an even surface both inside and outside. At Százhalombatta, we find that there are different Vatya houses used on the settlement at one time. There are houses with one, two or probably even with three rooms. Each house has at least one hearth or fireplace. Although, having more than one cooking/baking/roasting surfaces/structures in one house appears to be more common, than having only one hearth (Vicze 2013).

Clay seems to be one of the most regularly used building material at the site (Kovács and Vicze 2019). It is used in a wide range including walls, floors, hearths, pottery and also 'furniture-like' inner constructions such as boxes, weights (e.g. loom-weights) etc. (see Vicze 2013). Clay is an easily accessible raw material and with diverse tempering and composition it can be used extensively for different constructions (see with further references Kovács and Vicze 2019; also, for clay in general Sofaer 2015). During our excavation at Százhalombatta-Földvár we carefully study and document these diversities. With that, we wish to recognize the technological knowledge, the knowhow, and also some of the decisions behind specific raw material choices and their application. Part of our thin section soil micromorphological and phytolith sampling was focused on these questions, especially when during excavation we have realized, that in contrary to our previous knowledge and expectation, different raw material was used for similar constructions. This article is one of the studies discussing the results of our detailed interdisciplinary research methods and the first one testing the conjoint application of thin section micromorphology and phytolith analysis. Whilst micromorphological analysis is an eligible method to observe, describe and understand the nuances of building technological choices, phytolith analysis adds the
Fig. 1 Location of Százhalombatta-Földvár Bronze Age fortified settlement within Hungary; the position of the settlement on the loess plateau: the yellow line indicates the hypothesised extension of the site, which was partly destroyed by the fluvial expansion of the Danube and partly by anthropogenic landscape modifications (brick factory clay mining); dashed red line shows the currently known tell boundaries, red square delineates the excavation trench (modified after Vicze 2005)) aerial view of the site with the boundary of the tell (dashed red line) and that of the excavation trench (red continuous line)

vegetal component to the picture by describing the vegetal remains found within the studied anthropogenic material. The main aim of the paper is to determine how space was created through various material choices in the MBA, whilst the integrated analysis of two different methods is also challenged.

\section{Geographical setting of Százhalombatta-Földvár}

From the geographical point of view, SzázhalombattaFöldvár is part of the Mezőföld mesoregion and lies within the Érd-Ercsi-hátság microregion, which is bordered by the Danube from the east (Marosi and Somogyi 1990) (Fig. 1). The geomorphology of this area was created by multiple geological processes. During the Middle Pliocene clay deposits were formed as a result of the transgression of the Pannonian Sea. Due to intensive tectonic movements chessboard-like surface was formed (Pécsi 1967). During the Pleistocene fluvial erosion produced complex valley systems in this landscape, and areas that were left intact of these geological processes emerged from the landscape and formed ideal places for later human occupation. Sediments accumulated in the valleys and atop of the higher elevation areas created the base of the latter soil development (Frisnyák et al. 1977).

A ridge built up of the Upper-Pannonian (MiocenePliocene) Somlói Formáció $\left({ }^{\mathrm{so}} \mathrm{Pa}_{2}\right)$ stretches in a northwestern direction from the Danube bend (Gyalog 2005). Loess $\left(\mathrm{eQp}_{3}{ }^{1}\right)$ mosaics on the surface form plateaus and the site is located on the very proximity of the Danube overlooking the river bend and the flat alluvial area of the Csepel Sziget. Detailed description of the geological layers of the site was summarized by Kalmár (2005), while detailed pedological studies were conducted by Varga (2000) and Füleky (2005). In general, Százhalombatta-Földvár is located within a chernozem mosaic developed on loess parent material.

\section{Thin section soil micromorphology and phytolith analysis}

Thin section soil micromorphology is a microscopic technique capable of investigating micro-contexts and micro-fragments 


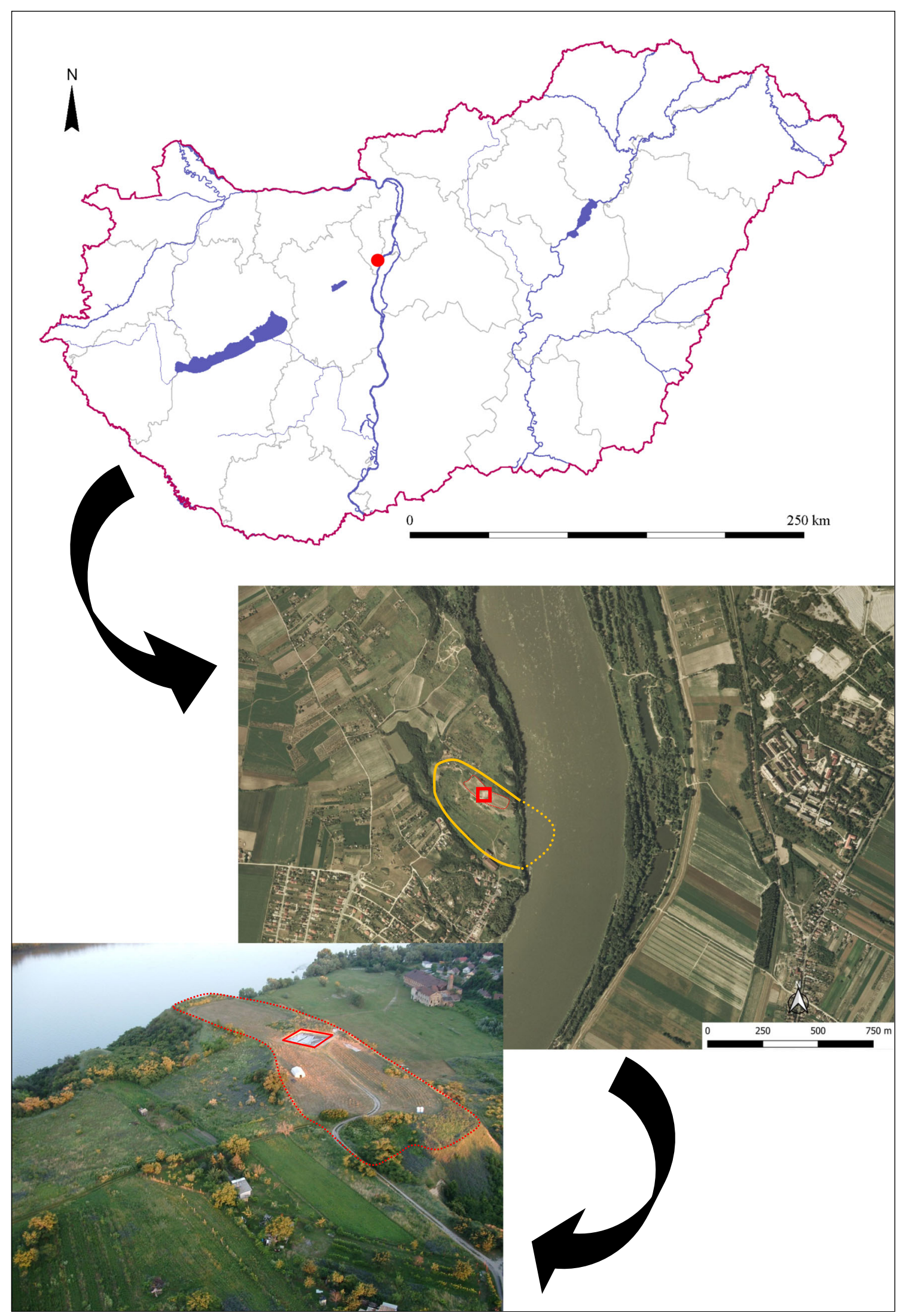


in great detail. Therefore, it is more and more frequently used in archaeological investigations (e.g. Portillo et al. 2019; Devos et al. 2013a, b, 2017 or see Nicosia and Stoops 2017 for extended literature and Banerjea et al. 2013 for experimental studies). Although it can be adopted to very largescale investigations (e.g. Courty et al. 1989; Goldberg 1992; French 2003), in this paper, it will only be challenged to answer questions regarding how space was created and used, and what material choices were made in the case of a Middle Bronze Age Vatya house.

Plant opal particles are hydrated silica bodies accumulated in different plants' organs by numerous plant taxa in the interand intracellular space and cell walls (Piperno 1988). Due to the fact that - on a long, even geological, time scalephytoliths are highly resistant to a broad spectrum of environmental factors (Blinnikov 2008), plant opal particles can be utilized both in palaeoecological and archaeobotanical studies as an environmental and palaeo-ethnobotanical proxy (Rovner 1971; Korstanje and Babot 2007, 2008; Madella et al. 2013) The potentials of phytolith analysis have been demonstrated (Piperno 1988, 2006) and reviewed in many fields of environmental, (archaeo)botanical and archaeological studies (e.g. Shilito 2011).

Thin sections are not widely used in phytolith studies due to their 2D nature. Phytoliths can be best investigated and observed under light microscope when recovered from soil and (anthropogenic) sediment material (Vrydaghs and Devos 2018). However, the combination of the two methods proved to have certain advantages in the understanding of space usage and man-plant relationships within urban and settlement contexts (e.g. Devos et al. 2009, 2013a, 2013b, 2017, 2020). Thin sections are limited to the cut angle, which might not be sufficient for the proper identification of the various phytolith morphotypes. Aspects of the phytolith analysis within fixed microscopic environments - such as ceramic thin sections-were also discussed previously by Kreiter et al. (2013, 2014), Pető and Vrydaghs (2016) and Vrydaghs et al. (2017). Phytoliths can be used as a proxy for identifying characteristics of vegetal material used for temper (Starnini et al. 2007; De Paepe et al. 2003; Lippi et al. 2011; Tomber et al. 2011; Kreiter et al. 2013). One of our aims is to determine the presence of vegetal temper in the different fabrics and an attempt will also be made to clarify the anatomical origin of the vegetal material.

Besides complementing the on-site archaeological observation of the building techniques with thin section soil micromorphological and phytolith analytical proxies, emphasis is given to the combined methodological approach of the two methods. Thin sections of anthropogenic sediments collected throughout a house (ID 3147) will be focused on in this paper to further test such conjoint method and to add taphonomic details to the micro-structure.

\section{Materials and methods}

\section{Feature no. 3147}

Remains of a Middle Bronze Age Vatya building (encoded as ID 3147 and referred to it as 'house' in the followings) were unearthed in the eastern part of the excavation trench. Unfortunately, the limits of the house exceed the dimensions of the trench, so only part of the building will be under inspection (Fig. 2). The dimensions of the house remain, available for investigation, are approximately $5 \times 9 \mathrm{~m}$. The house has two distinctive building phases encircled by walls, which are only partially preserved. No indication of inner/partitioning wall was detected in the excavated area. The intrusive pits of the later periods highly disturbed the eastern part of the construction. Two hearths were discovered in the northern part of the house, close to the trench wall. The hearths were built exactly at the same locale, both of them belonging to only one of the two phases.

\section{Phase nr. 1}

Earthen floor was detected in relation to the 1st building phase of the house. Although field documentation registered the possibility of several occupation surfaces and the presence of earthen floors, they could not be distinguished convincingly with traditional field archaeological techniques. The greyish-brownish colour of the earthen floors is identical to the colour/texture (loam/sandy loam) of the general sediment matrix (also called as general fill of the tell; for more details, see Füleky 2005; Kovács 2005, 2009), therefore really difficult to identify (Fig. 2b).

\section{Phase nr. 2}

The second building phase of the house is distinctively outlined by the yellow clay floor (Fig. 2c).

\section{Sampling methods and strategy}

Various parts of the house (e.g. earthen floor, clay floor, wall and hearth) were sampled for the characterization of the construction materials and for the detection of changes in material choice. Table 1 shows the full inventory of the analysed micro-horizons.

Four samples were investigated in relation to the floors (MS5 2004, MS7/1 2002, MS7/2 2002 and MS13 2004). Two samples are showing the wall of the house (MS10 2004 and MS21 2004) with an additional sample of a posthole (MS7 2004). One sample is representing the hearth of the 2nd phase (MS20 2004). 
a)
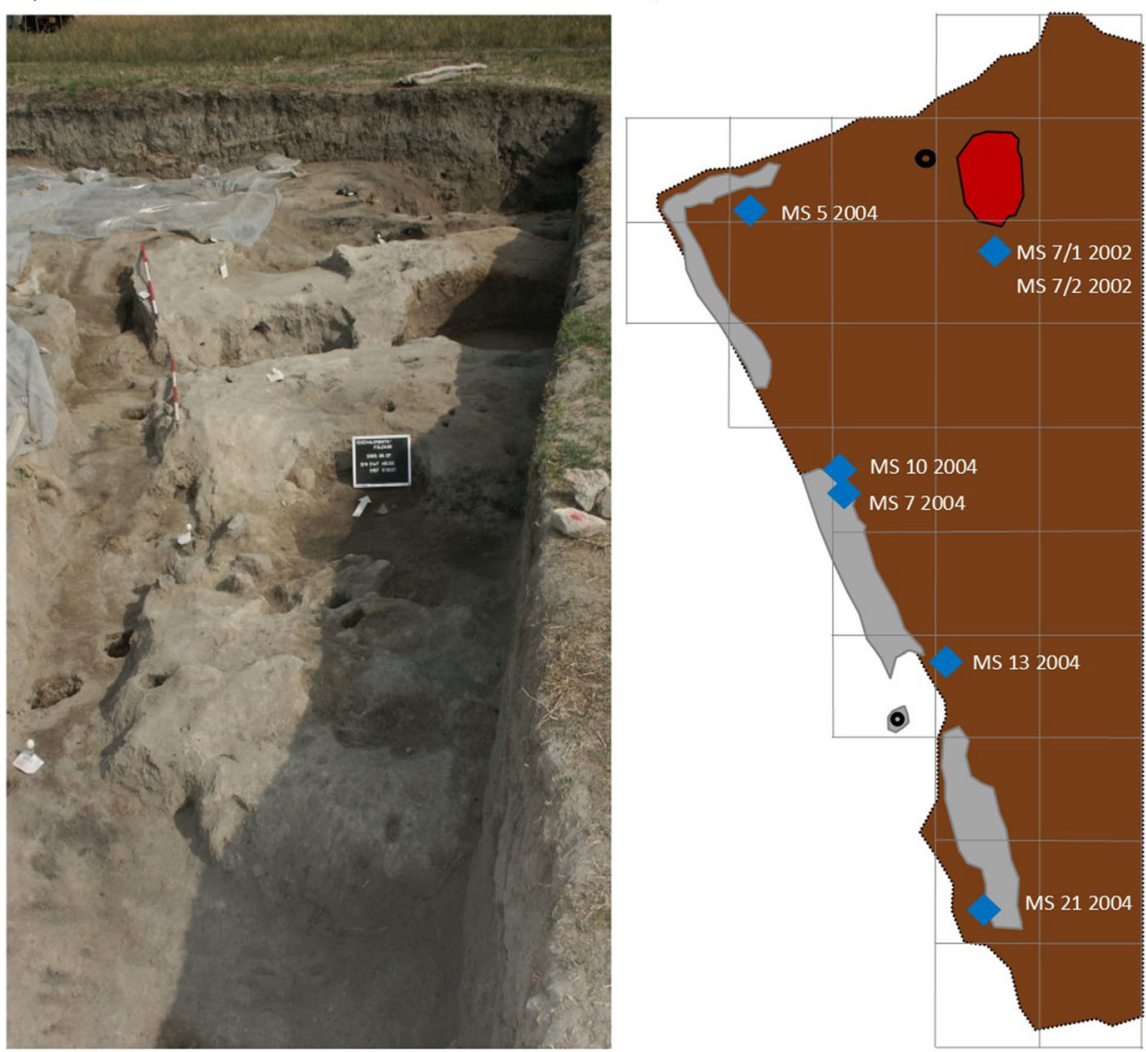

c)

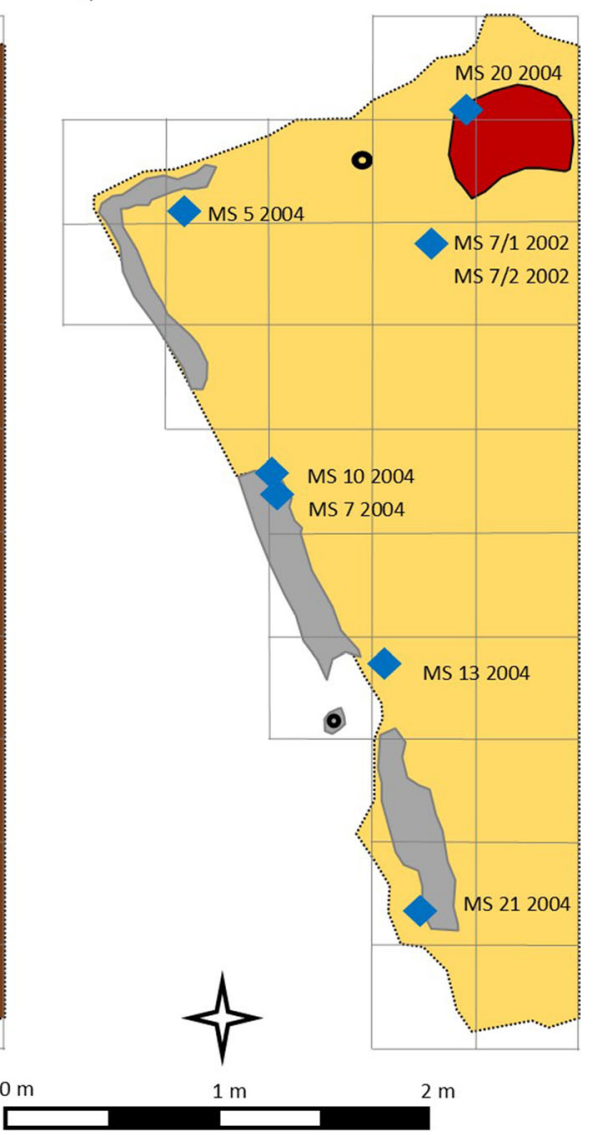

of wall structure; red: position of hearth; brown: earthen floor; yellow: clay floor; blue: position of the micromorphological samples
Fig. 2 a Photograph of MBA house after its excavation; b) ground plan of the house showing the 1st phase and the earthen floor; c) ground plan of the house showing the 2nd phase and the clay floor. Notes: grey: remains

\section{Methods of the thin section soil micromorphological and phytolith analysis}

Air-dried sediment blocks were impregnated and consolidated with unsaturated crystic polyester resin under vacuum out of which $30 \mu \mathrm{m}$-thin sections were prepared by cutting and grinding (Murphy 1986). Slides were then investigated under plane $(\mathrm{PPL})$ and cross-polarized light $(\mathrm{XPL})$ at $\times 20, \times 40, \times$ 100 and $\times 200$ magnifications with a Nikon Eclipse E200 polarizing microscope and described according to standard terminologies (e.g. Bullock et al. 1985; Stoops 2003).

Phytoliths, as well as silicified tissue elements, were analysed in the thin sections prepared for the soil micromorphological analysis at a magnification ranging between $\times 100$ and $\times 400$. Description of phytoliths was based on the International Code for Phytolith Nomenclature 2.0. (ICPT 2019). A modern reference collection of inflorescence bract elements of cereals and relevant scientific literature (Metcalfe 1960; Haraszty 1979; Miller Rosen 1992; Ball et al. 1996, 1999, 2017; Dickinson 2000) was used to identify the anatomical origin of the observed morphologies. Numerous criteria influence the visibility of phytoliths within a thin section (see
Kreiter et al. 2013, 2014; Pető and Vrydaghs 2016; Vrydaghs et al. 2017). The phytolith analysis of the thin sections implied five direct indices:

1. The Observed/Not Observed Index $(\mathrm{O} / \mathrm{NO})$ refers to the absence or presence of phytoliths within the thin section.

2. The Distribution Index (D) defines whether the observed phytoliths occur in the fabric or in voids.

3. The Morphotype Identification Index (MI) implies the identification of the plant opal particles observed in the thin section. It relies on standard phytolith nomenclature sources such as the ICPN 2.0 (ICPT 2019), and on plant anatomical knowledge.

4. Aspect Index (A) considers the plant opal particles individually in terms of their visibility and appearance. Visibility refers to the fact that phytoliths might be wholly, partly or not at all released from the organic tissues (for details check ESM 2.)

5. The Associated Material Index (AM) provides additional contextual data relevant to the presence or absence of plant opal particles, as well as defines the presence of charred plant organic matter (POM). 
Table 1 Inventory of the analysed micro-horizons and their context

\begin{tabular}{|c|c|c|c|c|}
\hline Sample code & Description & Stratigraphy/microlayers & $\begin{array}{l}\text { Archaeological context of the } \\
\text { stratigraphical unit }\end{array}$ & Development phase \\
\hline MS5 2004 & Earthen floors and related microlayers & $\begin{array}{l}\text { E5 } \\
\text { E4 }\end{array}$ & $\begin{array}{l}\text { Earthen floor } 5 . \\
\text { Earthen floor } 4 .\end{array}$ & 1st phase \\
\hline MS7/1 2002 & Earthen floors and related microlayers & E5 & Earthen floor 5. & 1st phase \\
\hline MS7/2 2002 & Earthen floors and related microlayers & $\begin{array}{l}\text { E5 } \\
\text { E4 } \\
\text { E3 } \\
\text { E2 } \\
\text { E1 } \\
F\end{array}$ & $\begin{array}{l}\text { Earthen floor } 5 . \\
\text { Earthen floor } 4 \text {. } \\
\text { Earthen floor } 3 \text {. } \\
\text { Earthen floor } 2 \text {. } \\
\text { Earthen floor } 1 \text {. } \\
\text { Foundation/sediment matrix }\end{array}$ & 1st phase \\
\hline MS13 2004 & Earthen floors and related microlayers & $\begin{array}{l}\mathrm{E} 5_{\mathrm{d} 2} \\
\mathrm{E} 5_{\mathrm{d} 1} \\
\mathrm{E} 5 \\
\mathrm{E} 4\end{array}$ & $\begin{array}{l}\text { Plant matter (dump) (on earthen floor) } \\
\text { (Ad hoc) sand dump (on earthen floor) } \\
\text { Earthen floor } 5 . \\
\text { Earthen floor } 4 .\end{array}$ & 1st phase \\
\hline MS7/1 2002 & Clay floors and related microlayers & $\begin{array}{l}\mathrm{SM} \\
\mathrm{C}_{\mathrm{ud}} \\
\mathrm{C}\end{array}$ & $\begin{array}{l}\text { Sediment matrix } \\
\text { Unburnt debris (on clay floor) } \\
\text { Clay floor }\end{array}$ & 2nd phase \\
\hline MS7/2 2002 & Clay floors and related microlayers & $\begin{array}{l}\mathrm{C}_{\mathrm{fb}} \\
\mathrm{C} \\
\mathrm{C}_{\mathrm{c} 1}\end{array}$ & $\begin{array}{l}\text { Floor build-up (on clay floor) } \\
\text { Clay floor } \\
\text { Clay matter (under clay floor) }\end{array}$ & 2nd phase \\
\hline MS13 2004 & Clay floors and related microlayers & $\begin{array}{l}P \\
C_{f b} \\
C_{a 3} \\
C_{a 2} \\
C_{a 1} \\
C \\
C_{p} \\
C_{c}\end{array}$ & $\begin{array}{l}\text { Plaster fragment (clay) } \\
\text { Floor build-up (on clay floor) } \\
\text { Ash layer } 3 \text { (on clay floor) } \\
\text { Ash layer } 2 \text { (on clay floor) } \\
\text { Ash layer } 1 \text { (on clay floor) } \\
\text { Clay floor } \\
\text { Packing material } \\
\text { Clay matter (under clay floor) }\end{array}$ & 2nd phase \\
\hline MS5 2004 & Clay floors and related microlayers & $\begin{array}{l}\mathrm{C}_{\mathrm{fbb}} \\
\mathrm{C} \\
\mathrm{C}_{\mathrm{c} 2} \\
\mathrm{SM} \\
\mathrm{W}_{\mathrm{p} 1} \\
\mathrm{~W}_{\mathrm{p} 2} \\
\mathrm{~W}_{\mathrm{p} 3} \\
\mathrm{~W}_{\mathrm{p} 4}\end{array}$ & $\begin{array}{l}\text { Floor build-up/burnt organics } \\
\text { Clay floor } \\
\text { Clay matter } \\
\text { Sediment matrix } \\
\text { Wall plaster (clay) } \\
\text { Wall plaster (clay) } \\
\text { Wall plaster (clay) } \\
\text { Wall plaster (clay) }\end{array}$ & 2nd phase \\
\hline MS10 2004 & Wall-building technique & $\mathrm{W}_{\mathrm{s}}$ & Wall material/sediment matrix & $1 \mathrm{st} / 2$ nd phase \\
\hline MS21 2004 & Wall-building technique & $\mathrm{W}_{\mathrm{s}}$ & Wall material (sediment type) & 1st/2nd phase \\
\hline MS7 2004 & Wall-building technique & $\begin{array}{l}\mathrm{W}_{\mathrm{p}} \\
\mathrm{W}_{\mathrm{s}}\end{array}$ & $\begin{array}{l}\text { Wall plaster (clay) } \\
\text { Sediment matrix/wall base }\end{array}$ & 1st/2nd phase \\
\hline MS20 2004 & Hearth & $\begin{array}{l}\mathrm{W}_{\mathrm{hc} 1} \\
\mathrm{~W}_{\mathrm{hc} 2} \\
\mathrm{~W}_{\mathrm{hc} 3} \\
\mathrm{~W}_{\mathrm{hc} 4}\end{array}$ & $\begin{array}{l}\text { Hearth wall (clay) } \\
\text { Hearth wall (clay) } \\
\text { Hearth wall (clay) } \\
\text { Hearth wall (clay) }\end{array}$ & 2nd phase \\
\hline
\end{tabular}

Abbreviations: $E$, earthen floor; $C$, clay floor; $P$, plaster; $S M$, sediment matrix; $W$, wall-related material

The description protocol of the micromorphological analysis approach provides semi-quantitative data based on the identification of the relative amount of plant material (organic and inorganic) observed within a sample. This is complemented by the identification of the relative abundance of plant temper in the fabric material based on the presence of pseudomorphic plant voids (i.e. vegetal voids) (Matthews 1995; Shillito et al. 2011), phytolith aggregates, as well as 
on not perfectly undecayed plant material in the thin section. Empty voids (e.g. vegetal voids) of the thin sections (besides air bubbles) are the places from where plant organic material was completely decayed out (in contrast to the ceramic fabric, where voids are representatives of plant material burn out during the process, see Petö and Vrydaghs 2016 for methodological considerations and Kreiter et al. 2013, 2014 for application). Still, phytoliths and various forms of charred - and in many cases amorphous - plant material might also occur in the matrix and in voids as well. Charred organic plant material is referred to as POM (plant organic matter) within this study.

Since phytoliths are produced in the tissues and cell lumens of the plant, the primer in-put of phytoliths to the clay material is conscious plant tempering. As a secondary process, plant parts maybe incorporated into the clay when the raw material is stored or deposited during the production and/or utilization process.

The term 'chaff' in petrographic and micromorphological analysis (Nicosia and Canti 2017) is generally used to identify plant tempering; however, the botanical meaning might differ to how it is used in archaeological studies. From the ethnographic point of view chaff is the by-product of the cleaning process of harvested (hulled) cereals, regardless of the cereal species. From the botanical point of view chaff implies parts of the generative organ (inflorescence), such as the glumes, the palea and the lemma that produce phytoliths (Metcalfe 1960; Parry and Smithson 1966; Ball 1992; Ball et al. 1996, 1999). All these can be grouped under the term of husk, because of the similarity of the cell morphology in the epidermal tissue and their possible frequent occurrence in archaeological samples (Miller Rosen 1992: 131; Ball et al. 2017).

\section{Results and discussion: Combining the evidence}

The combined and integrated utilization of archaeological thin section soil micromorphology and phytolith analysis in fixed analytical environment (cf. thin section scanning) aimed at reconstructing certain moments and details of the taphonomy and development of a MBA house at SzázhalombattaFöldvár. Although the conjoint application of the aforementioned two methods cannot be considered comprehensive, it still provides valuable details to the traditional archaeological techniques. Data gained through the micromorphological and phytolith observations within the thin section collected at house ID 3147 shed light on the development of earthen and clay floors, as well as on material and technique choices made by the population of the tell settlement.

Detailed results of the micromorphological analysis is summarized in ESM 1, while those of the phytolith analysis is given in ESM 2.

\section{Earthen floors (phase nr. 1)}

Ten micro-layers in four thin sections (Table 1) of various locales exhibited the earthen floor phases of the house. Figure 3 shows that in total five earthen floors (MS7/2 2002 E1-E5) were prepared on the initial foundation surface (MS7/2 2002 F). Since MS7/2 2002 is the only sample that contains the full series of the earthen floors, this sample will be discussed in detail and only differences will be highlighted in relation to the other thin sections in order to track horizontal variations and changes of space use. Unfortunately, samples MS5 2004 (E4 and E5), MS7/1 2002 (E5) and MS13 2004 (E4 and E5) only capture the last one or last two earthen floors of the house (see Table 1 for stratigraphic clarifications).

The foundation surface, compared with the material of the earthen floors themselves, is less compact. The somewhat higher rate of porosity seems to be the result of enhanced bioturbation. This horizon contained decomposed plant matter, which was observed in the form of phytoliths $(<2 \%)$ and dung fragments (in forms of articulated phytoliths and calcite spherulites (e.g. Canti 1998)) (2-5\%). This latter is considered here as the subject of micro-faunal attack. The foundation layer is a mixture of domestic waste (dung, charcoal, bone, burnt bone, ash, pottery, daub and plaster fragments) and sediment particles (quartz, polycrystalline quartz, muscovite, biotite, chlorite and Sarmathian limestone fragments) (ESM 1). This composition is exactly what defines some of the general matrix (fine structured, sandy loam/loam with varying amount of anthropogenic inclusions-Füleky 2005) of the site. (For more detailed characterization of general fills see also Kovács 2009). In this case it shows some levelling, which is indicated by the sharp, straight boundary between the foundation layer and the overlying 1 st earthen floor. It seems that the previously accumulated settlement material served as a foundation for the house. In comparison to the earthen floor, the foundation layer shows higher amounts of inclusions on a wider scale, which suggests that the house was built on a surface that enclosed various refuse elements. It has to be also noted here that the anthropogenic inclusions are rather small in size in this layer, which indicate that the bigger refuse elements were removed during the preparation of the foundation surface. With other words, the general fill of the tell was used for sub-floor levelling, and the cleaned and sorted version of this same material was used for creating a structured floor surface consequently. In the case of Százhalombatta the differences between the sub-floor levelling material and the first earthen floor layer lies within the amount and intensity of anthropogenic inclusions. In this sense there are both similarities and differences to ethnoarchaeological observations recorded during the micromorphological study of floors in experimentally built huts. Banerjea et al. (2013) reports on the usage of various earth materials transported from elsewhere into the inner space of the huts for the sake 


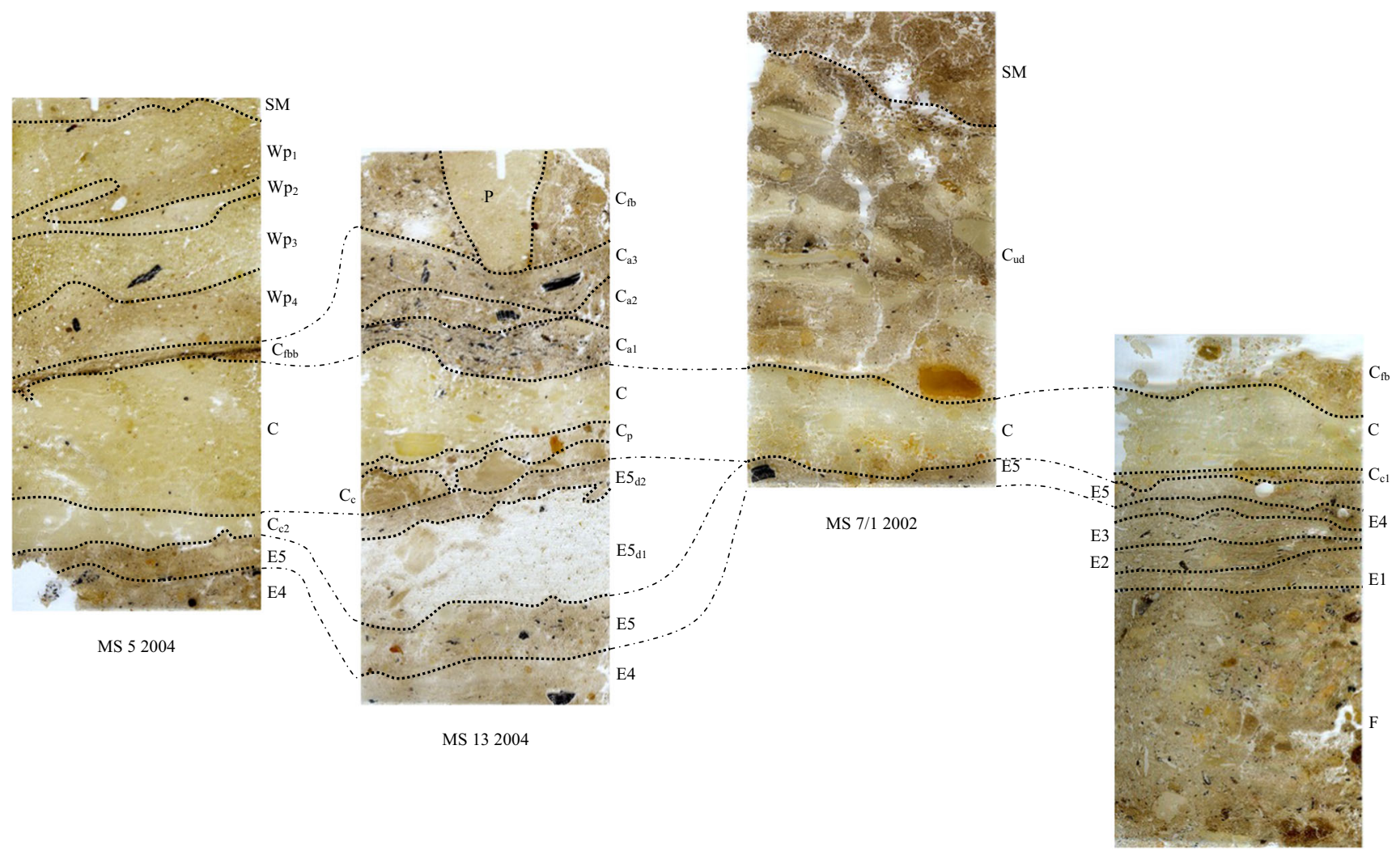

MS 7/2 2002

Fig. 3 Stratigraphic links between the microlayers of the house on sample MS 5 2004, MS13 2004, MS 7/1 2002 and MS 7/2 2002

of sub-floor levelling and for preparing an even surface within the buildings. According to their observations the strength of the material was exaggerated by deliberately modifying the earth material or even adding vegetal temper to it. At Százhalombatta the contrary seemed to be true. The texture of the general fill (see Varga 2000 and Füleky 2005 for soil physical data) was suitable for creating a non-cracking even surface if the larger anthropogenic inclusion were removed.

According to the micromorphological observations the foundation layer (MS7/2 2002 F) is a mixture of microscopic domestic waste incorporated in the sediment matrix. This statement is underlined by the results of the phytolith analysis. Neither structured plant deposition, nor in situ plant deposition was detected here, which refers to the fact that the anthropogenic material of this layer was not tempered and it may have gone through multiple steps of (cleaning or sorting?) management, which is also indicated for example by the turbation of the material. It is interesting to note that evidence of both monocot and dicot species were detected. Since the evidence and indicators of cereals can be found all over the site both within the micro- and the macro-archaeobotanical record (Stika and Heiss 2012, 2013; Vretemark 2011), it is not surprising that indicators of grass generative (e.g. ELO_ENT) and vegetative organs (e.g. chaff material) in the form of elongate dendritic (ELO_DEN) and grass silica short cell (GSSC) morphotypes were detected (ESM 2). Silicified tissue elements are not found in anatomically sound position, signs of degradation and (bio)turbation are anticipated in this layer. The appearance of possible dicot species is significant as they most probably reflect the natural vegetation of the site and do not derive from the cultural flora. However, we cannot identify whether these botanical elements were consciously brought in and used in the settlement, or they represent contamination from the environment.

Sample MS7/2 2002 was taken from the northern part of the house near the hearth, which seems to nicely explain the enhanced amount of ash and charcoal all the way through the various earthen floor layers (E1-E5) in this sample (Fig. 4 a and b). However, the ash accumulations neither form distinctive horizons, nor zones, which suggest that they are not the in situ results of hearth rake-out activity, but only indicators of such events. Furthermore, if we compare the rest of the data from the other thin sections, it becomes evident that all the investigated earthen floors exhibit enhanced amounts of ash and charcoal (ESM 1). This shows that the initially described sample is not loaded with firing remains due to the locally ongoing activity (e.g. firing, cooking), but it seems that ash was used throughout the house. On the other hand, the ash is incorporated into the floor matter and not sitting on top of it distinctively. This indicates that ash was actually added to the 


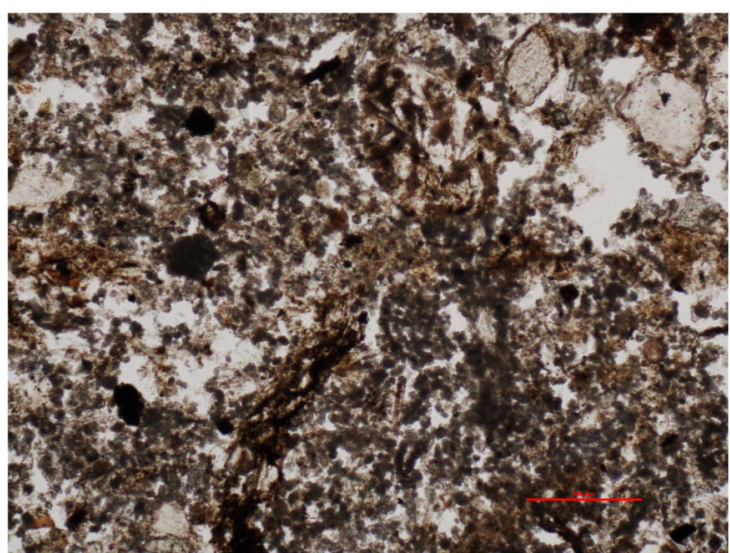

a)

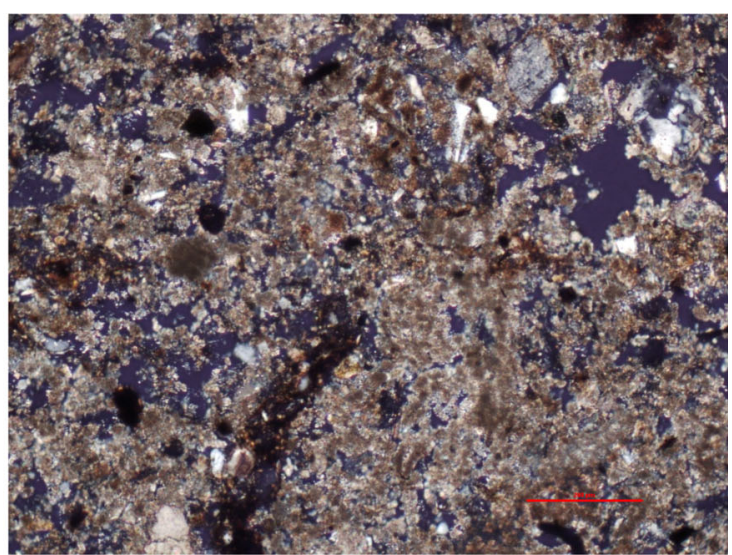

b)

Fig. 4 General matrix of the earthen floor as documented in sample MS7/2 2002. a PPL; b XPL

flooring matter. If it would have been only trampled into it, it would be appearing in the top zone rather than throughout the microlayers.

There is no significant difference between the mineral compositions of the five earthen floor horizons within sample MS7/2 2002. The same could be observed in the other thin sections exhibiting the earthen floors of the house (ESM 1). Quartz and polycrystalline quartz occur with higher frequency in all floor layers with additional muscovite, glauconite, biotite and chlorite minerals. Sarmatian limestone fragments were only observed in the foundation layer and in the oldest floor layer of sample MS7/2 $2002 \mathrm{E} 1$, suggesting that the limestone particles were only derived from the general sediment matrix on which the house was built. Their small number does not suggest intentional use of this material.

Structured plant deposition was not detectable within the first earthen floor of the house (MS7/2 2002 E1). The dominant GSSC morphotypes that were detected within this layer together with elongate entire (ELO_ENT) and elongate echinate (ELO_ECH) phytolith morphologies represent grass stem and leaf tissues, and it is important to note that signs of cereal chaff were not detected at all. The relative low appearance of mainly disarticulated phytoliths refers to an anthropogenic environment, which did not come into connection with significant amount of plant material over a longer period of time. With other words, the sediment used for creating the earthen floor of the house can be considered a substance free of conscious vegetal tempering. This observation is in accordance with the micromorphological description, which defined this floor material as a very finely grained and strongly compacted material. The second earthen floor (e.g. MS7/2 2002 E2) not only contains small charcoal particles, but charred grass tissue elements (POM) were also recorded. In addition, the articulated silicified sheet elements most likely represent small parts (chopped?) of cereal chaff (cereal cleaning by-products) (Anderson et al. 2004 and Anderson et al. 2006 reported on silica sheet elements with similar 'cut profile' using threshing sledge in an experimental archaeological study.)

The appearance of well-structured plant material in earthen floor MS7/2 2002 E3 is a novel phenomenon within the development of the house. The in situ plant material represents the leaf, stem and inflorescence material of cereals. Since this phenomenon was not detected in other earthen floor layers, it is hard to identify whether these vegetal remains occur in the floor material accidentally, or they are consciously integrated into it for some reason.

In contrast to earthen floor MS7/2 $2002 \mathrm{E} 3$, phytoliths within earthen floor MS7/2 2002 E4 are almost solely disarticulated ones, which are integrated into the fabric material. No structured plant deposition can be described. Phytolith morphotypes appear in the fabric, and are disarticulated meaning that they are released from the plant tissue. This combination can be linked to the fact that these plant opal particles were originally integrated to the base material used for preparing the floor and their appearance in earthen floor E4 is only secondary. Earthen floor E4 in sample MS5 2004 showed very similar traits; the micromorphological observations underline their common genetic roots within the development of the house.

The relatively high phytolith presence seems to eliminate in the last earthen floor of the 1st building phase. Earthen floor MS7/2 2002 E5, which 'seals' the first building phase contains higher amount of ash and micro-charcoal fragment than intact disarticulated or articulated phytoliths. Signs of chaff presence or any structured deposition could not be proven. Microlayer MS5 2004 E5 is genetically identical with the abovementioned one in sample MS7/2 2002. As a parallel phenomenon, this earthen floor layer showed similar micromorphological traits, since the presence of high amounts of charcoal was proven, while the phytolith content was identified to be moderate/low. Both samples of E5 floor were lacking any structured plant deposition. 
None of the examined samples (thin sections) show debris accumulation between the earthen floor layers. This suggests regular cleaning and maintenance. Charcoal and ash are the most abundant inclusions in the floor matter, as was implied above. In case of firing, via the melting of mineral components, so-called non-metallurgic slags are formed. Their occurrence in the earthen floors is therefore also an indicator of heat/firing. However, there is no sign of in situ firing in the analysed horizons, so all the charred remains and ash together with the non-metallurgic slag fragments are in secondary position. It seems that they were added to the sediment to create the floor matter. Phytoliths are also frequent. The amount of bone, pottery and daub fragments within the floor matrix is low. They are tiny in size and are indicators of domestic context (i.e. remnants of everyday life). This indicates that the general sediment matrix of the settlement was used for flooring after some treatment. The fine $(0.5-1 \mathrm{~cm})$, thin floors have no physical capacity to capture macro-finds and it seems that floors were generally laid with care (see Kovács and Vicze 2019) and only previously 'cleaned' building matter was employed. The absence of accumulated debris makes it impossible to detect the range of activities that may have taken place, with the exception of cleaning. The observed $0.5-1 \mathrm{~cm}$ thickness of the earthen floors is believed to be only portion of the original floor. The scraping of the floor surface — prior to renewal-was already discussed in relation to the clay floors at SzázhalombattaFöldvár (Kovács and Vicze 2019), so we propose that the same technique was used here as well.

The composition of the five earthen floors shows great similarity. However, differences can be spotted when their horizontal position is taken into consideration.

The earthen floor layers from the southern part of the house (MS13 2004 E4 and E5) (Fig. 5), has higher amounts of ash content. The ash (Fig. $5 \mathrm{a}$ and b) is part of the floor matter and not sitting on top of it. This however not only suggests purposeful addition (the general sediment matrix does not contain this elevated amount of ash (see Kovács 2009)) but also shows the application of various mixes between the eastern and southern areas. In this sample there are several in situ decomposed plant remains. They are present within the floor matrix (E4, E5) and there is some surviving plant matter (Fig. $5 \mathrm{c}$ and $\mathrm{d}$ ) on top of a probable ad hoc sand dump (E5 $\left.\mathrm{d} 1_{1}\right)$ (Fig. $5 \mathrm{e})$. The preservation was due to the sheltered position of the sampled locale (right next to the wall). At one hand, phytolith indicators represent local, in situ deposition of both grassmost likely cereal — vegetative (stem and leaf) and generative (chaff) material. Besides, relatively high amount of charred plant material could also be detected in the form of POM and charcoal fragments (Fig. 5b). The simultaneous occurrence of grass stem, leaf and inflorescence material in the earthen floor (E5) matrix might be an indication of dung presence at the sampling location (Fig. 5f). This idea is further supported by the presence of faecal spherulites observed during the soil micromorphological analysis.
As the sample was taken immediately next to the wall, it is possible that some of the debris accidentally survived the sweeping. This is not surprising in areas that are not affected by heavy use/traffic and which are more 'protected' due to their location.

In sample MS13 2004 there is a sandy layer (E5 $\left.5_{\mathrm{d} 1}\right)$ on top of the youngest earthen floor, right under the plant horizon discussed above. So far it seems that this material is restricted to areas near the wall as it is missing from the rest of the samples. Based on the physical properties (cf. sand material with higher pore intensity) of this sand layer and the distribution of the silicified tissue elements within the sample it is anticipated that these are secondary depositions and are most probably the result of vertical downward infiltration processes that occur in the bigger pores of the sand fraction (e.g. Fishkis et al. 2009, 2010a, 2010b). This is further supported by the above lying in situ decomposed plant matter $\left(\mathrm{E} 5_{\mathrm{d} 2}\right)$, which is considered to have been lying outside the last major cleaning of this floor, which contains high amounts of cereal-related plant opal indicators. Micro-horizon E5 $\mathrm{d}_{2}$ can be identified as a structured deposition of cereal-related material. Although both generative and vegetative indicators appear in the assemblage the predominance of inflorescence indicators could have been detected, which refers to cereal cleaning by-products at this location. The phytolith signal of this layer undoubtedly shows the presence of chaff material at this point (i.e. next to the wall) of the house (Fig. $5 \mathrm{c}$ and d). Whether this assemblage derives from cereal cleaning activity within the house, or it marks a deposition of chaff material saved for further processing is hard to identify. However, it seems sure that a plant-derived deposition was found atop the floor.

\section{Clay floor (phase nr. 2)}

During the 2nd phase the entire floor surface was plastered with yellow clay (plaster) (see Fig. 3 and Table 1: MS7/1 2002 C; MS7/2 2002 C; MS13 2004 C; MS5 2004 C). Field observations only registered one clay floor layer that can be confirmed by the microscopic observations. No floor renovation or renewal can be detected in the analysed samples.

The mineral composition of the plaster floor in the northern and southern parts of the house is very similar, as was in the case of the earthen floors. The floor is composed primarily of fine mineral matter (Fig. $6 \mathrm{a}$ and $\mathrm{b}$ ) and it contains almost no anthropogenic inclusions (except for the occasional phytoliths and charcoal fragments). The samples illustrate that 'clean', very fine matter was used to build the floor and care was taken to exclude any debris from the surroundings. The floor plaster contains only a few phytoliths. Although the presence of elongate dendritic (ELO DEN) morphotypes could be proved, their sporadic distribution only account for a weak cereal signal in this layer. Moreover, the few articulated particle assemblages show heavy bioturbation. The absence of vegetal voids and organic staining, or any other form of plant material, clearly shows that no vegetal 


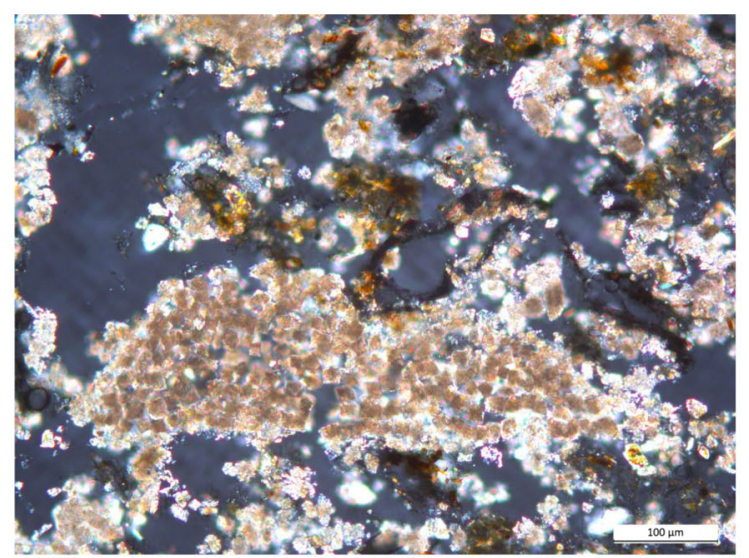

a)

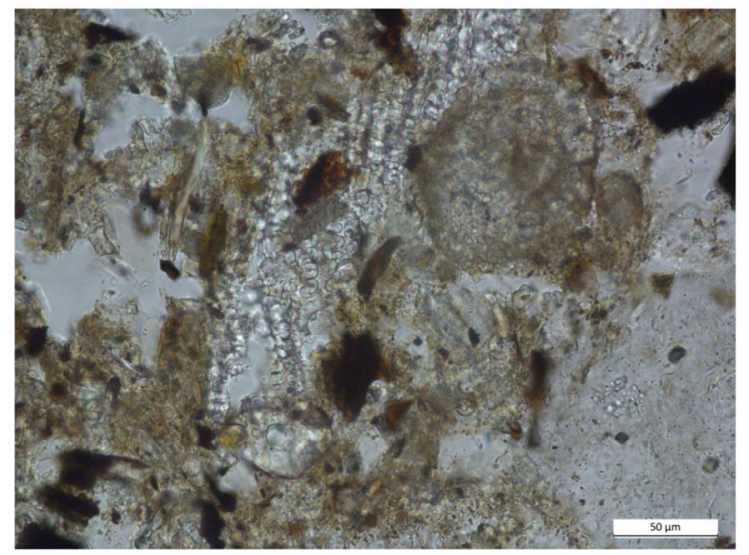

c)

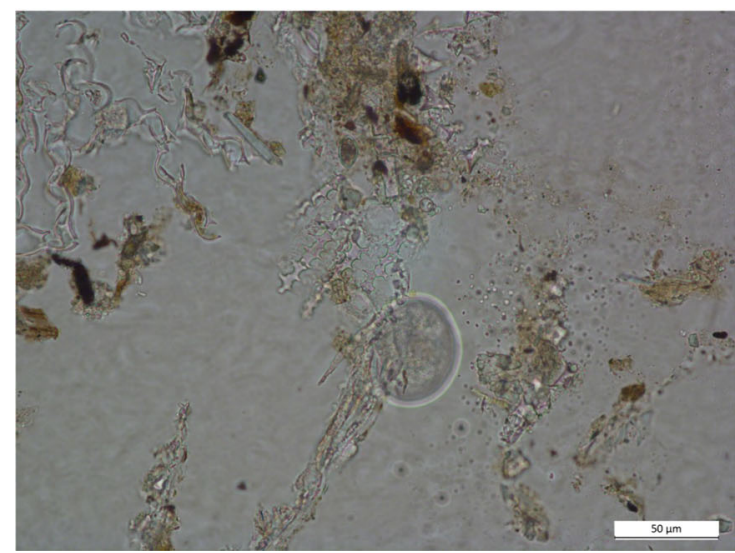

e)

Fig. 5 Phytolith occurrences in earthen floor E4 and E5 (Sample MS 13 2004). a Ash (XPL) and b charcoal fragment (PPL); c articulated cereal chaff remains showing in situ decomposed plant material (PPL); $d$ microlayers deriving from plant deposition (PPL); e ex situ partially

temper was added to the clay. The floor exhibited a low frequency of pore spaces and high compaction. This suggests that only moderate mixing of the raw material took place, which prevented

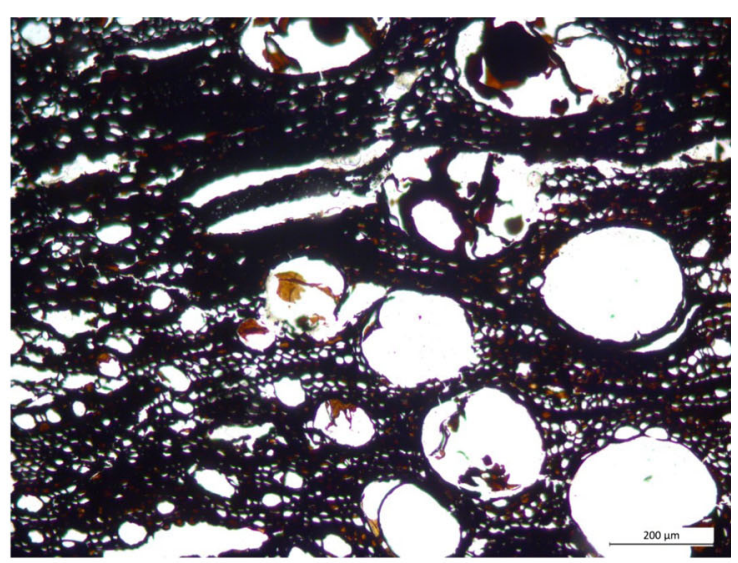

b)

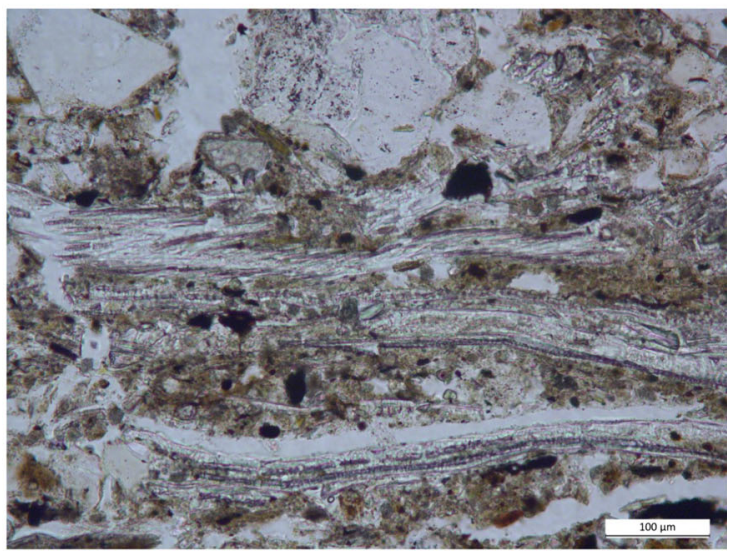

d)

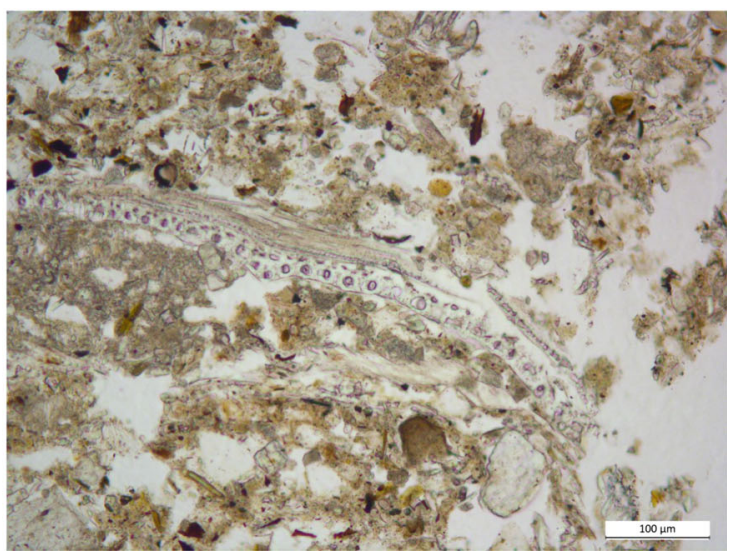

f)

disarticulated phytolith within the greater voids of the sand dump micro-horizon (PPL); f nicely preserved anatomical cross-section of cereal chaff material (PPL)

too much air being captured in the floor horizon, therefore it lacks voids. Presence of voids (i.e. air bubbles) is quite frequent when temper is added to the raw material (see daub later on). 


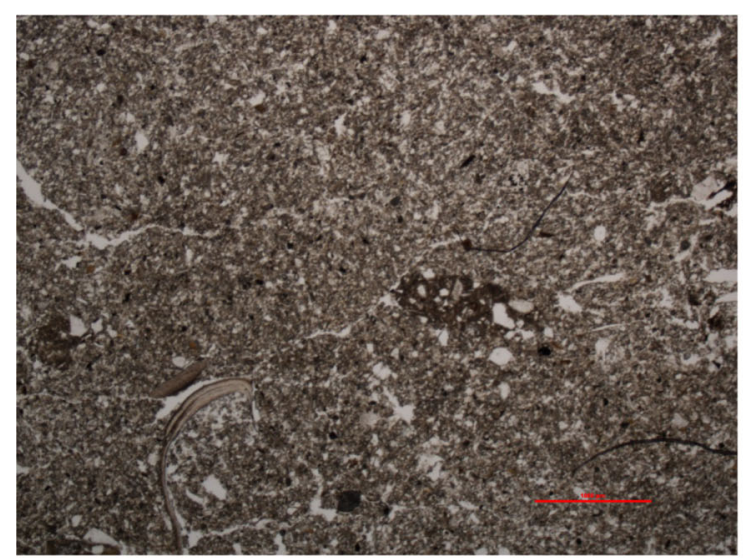

a)

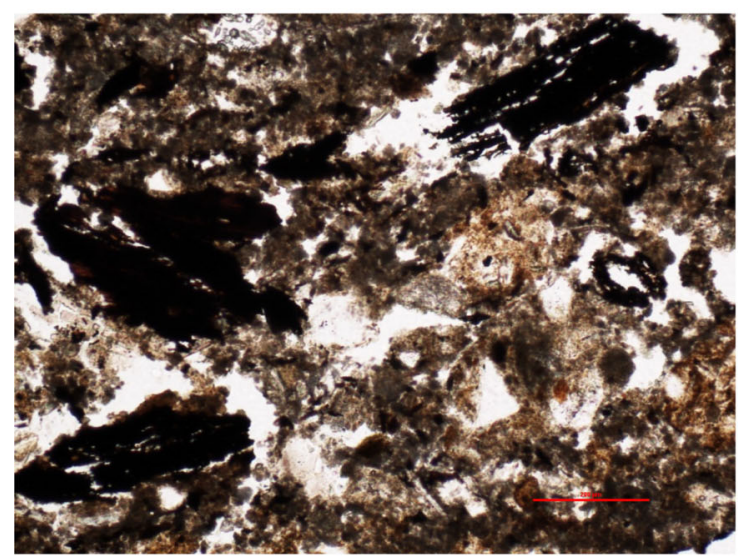

c)

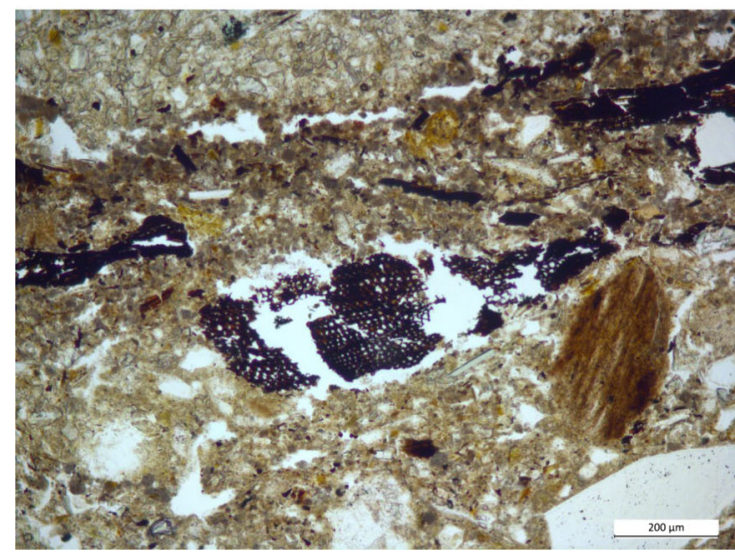

e)

Fig. 6 General matrix of the clay floor as documented in sample MS5 2004: a PPL; b XPL. Floor build-up on top of the clay floor composed of charcoal fragments and ash material in sample MS5 2004: c PPL; d XPL.

Pure clay matter is recognizable beneath the proper plastering in the case of sample MS5 $2004\left(\mathrm{C}_{\mathrm{c} 2}\right)$ (Fig. 3). However, this is not the case in sample MS7/1 2002. Since no plaster-floor renovation was detected, either

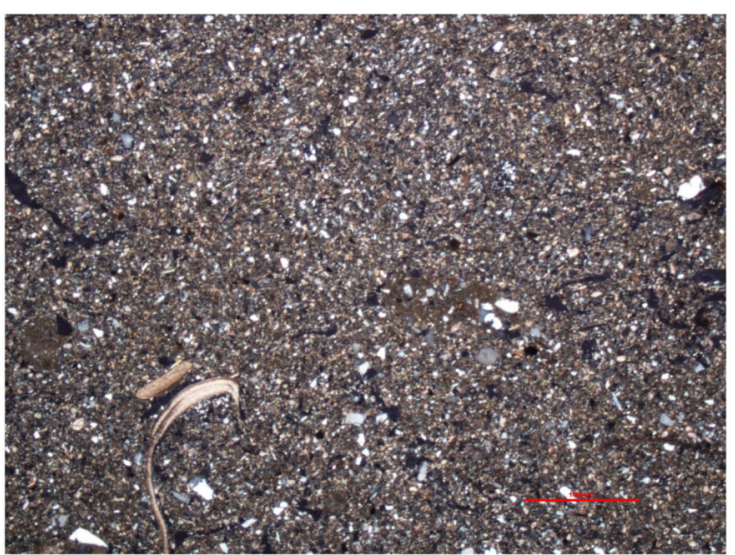

b)

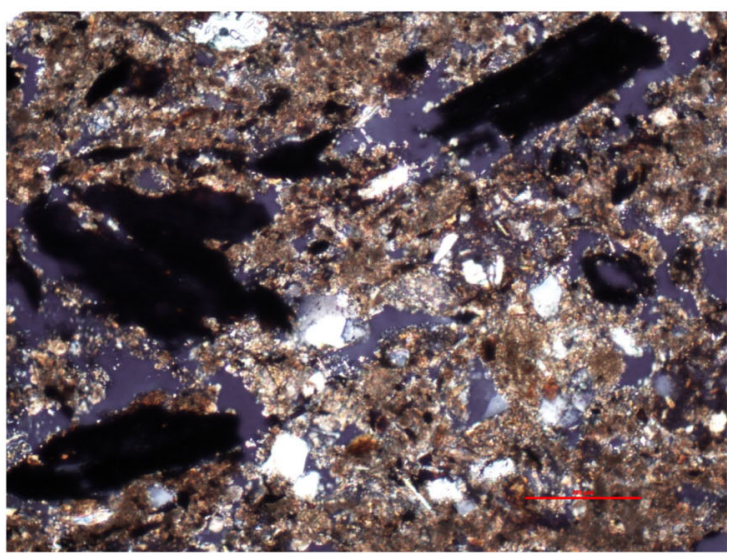

d)

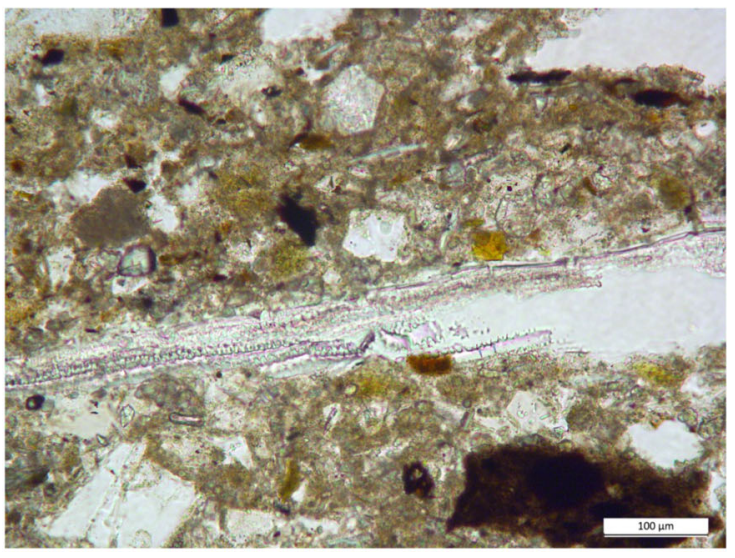

f)

Charred plant organic matter (POM) (e) and structured plant material (f) within the $\mathrm{C}_{\mathrm{fbb}}$ layer (PPL)

micromorphologically or archaeologically, it seems reasonable to believe that the clay appears here to eliminate unevenness prior to laying the clay floor (see KovácsVicze 2019). This hypothesis seems to be further 
supported by the fact that this sample with the 'extra' clay horizon was taken near the wall. The plaster floors were slightly raised-up to the walls to join the two elements (Kovács 2009), where the use of more building matter was beneficial to create the slight slope between the wall and the floor plaster. The 'extra' clay might have served this purpose.

The accumulated floor build-up on top of the clay floor in sample MS5 2004 (Fig. 6 c and d) is represented by a 1 to 2$\mathrm{mm}$ thick horizon $\left(\mathrm{C}_{\mathrm{fb}}\right.$; Fig. 3$)$ that is composed of pure ash, charcoal, other charred plant organic matter (POM) with significant amount of phytoliths (Fig. 6 e and f). This appearance of well-structured plant material is a novel phenomenon within this sample of the house. The in situ plant material represents the leaf, stem and inflorescence material of cereals. The sample contains only a thin layer of ash and no other remnants of domestic waste indicative of regular cleaning, just as we have seen in the case of the 1st phase in this area. The rest of the horizons on top of this layer represent fallen-in debris (mainly wall plaster fragments). One of the collapsed wall fragments contains some dung, which might indicate that it was used as temper. However, the amount of dung is small as is the amount of plant matter. This suggests that dung was not a significant element in the clay matter. Also, phytolith morphotypes appear in this fabric, and are disarticulated meaning that they are released from the plant tissue. This combination can be linked to the fact that these plant opal particles were originally integral parts of the clay material, and their appearance here is only secondary. In this sense they might be the representatives of wall material fallen onto the floor of the house.

The $\mathrm{C}_{\mathrm{ud}}$ microlayer in sample MS7/1 2002 shows the accumulated unburnt debris on top of the floor (C) (Fig. 3). The phytolith analysis showed that several plant deposition sublayers form this microlayer (Fig. $8 \mathrm{a}$ and b). The high amount of phytoliths show intensive bioturbation processes. It is evident after the first glance that this thin section (MS7/1 2002) does not contain an ash layer, which would be similar to the one observed in the previous thin section (MS5 $2004 \mathrm{C}_{\mathrm{fb}}$ ) (Fig. 3). This sample (MS7/1 2002) was taken very close to the hearth - an area that might have been kept regularly 'clean' - and this might account for the lack of floor buildup. Just as in the case of sample MS5 2004, this thin section also contains a considerable amount of wall fragments that seem to be collapsed debris after the abandonment and destruction of the house. However, the presence of charcoal, ash, vegetal remains (in the form of phytoliths and POM), bone and pottery fragments demonstrate the domestic context.

The southern area (MS13 2004, Fig. 2), nonetheless, shows a different picture. Three ash layers $\left(\mathrm{C}_{\mathrm{a} 1}, \mathrm{C}_{\mathrm{a} 2}\right.$ and $\left.\mathrm{C}_{\mathrm{a} 3}\right)$, which vary between 1.1 and $1.7 \mathrm{~cm}$, are visible on top of the clay floor (C). These consecutive ash layers and the orientation of their various components (parallel to the floor level), together with the sharp boundaries between the horizons, suggest deliberate placing. The exact aim of this action is hard to discern but it might have served hygienic purposes. Wood ash is highly calcareous (Karkanas et al. 2000), that is to say alkaline, so it can be used as a disinfectant (Hakbijl 2002). Furthermore, ash has a high capacity of water absorption, which makes it useful to reduce dampness, which is considered favourable within the internal living spaces (Milek 2006). Ash can also be used for odour elimination therefore it was commonly spread on earth floors (Milek 2000). There is no other type of debris accumulation between the ash layers, which hints at short periods of time between their formations or lack of activity here for some time. The presence of floor build-up $\left(\mathrm{C}_{\mathrm{fb}}\right)$ on top of the last ash layer $\left(\mathrm{C}_{\mathrm{a} 3}\right)$ shows that the area was used for another activity later on (Fig. 3). The floor build-up contains charcoal, phytoliths, ash, bone and non-metallurgic slag, all of which indicate domestic context that is to say everyday life. A fallen-in wall/plaster fragment occupies the majority of the floor build-up suggesting that this horizon was the last occupation surface after which the house was abandoned.

\section{Wall}

Two micromorphological samples are used to characterize the wall material and the building technique (samples MS10 2004 and MS21 2004). One of the postholes was also sampled (sample MS7 2004) (Table 1).

MS21 2004 represents the inner structure of the wall (Fig. 7). Its main composition can be characterized with the abundance of sediment particles. Various refuse elements (such as charcoal, ash, bone, organic matter etc.) were also identified in the horizon. Although (in contrary to the earthen floors) the sample contains some coarser (a couple of millimetres in size) inclusions (charcoal and bone, for example), it can be characterized as rather fine and compact. This part of the wall is made of the general sediment matrix of the tell, similarly to the earthen floors. However, in the case of the wall it seems that the material used was less carefully prepared. This is showed by the abovementioned coarser inclusions.

The material under investigation did not accumulate in situ. This is clearly indicated by the bone fragment and the brown material surrounding it. The bone was originally deposited elsewhere and the brown material surrounding it represents the original deposit in which it was lying. Later on, it was transported and incorporated into the matter that was used to prepare the wall (Fig. $8 \mathrm{c}$ and d). The same is true for the ash fragment (Fig. 8 e and f). No reddening of the enclosing matrix is visible, which clearly indicates that the actual burning took place somewhere else. These observations are also supported by the phytolith analysis of the layer. Both charred plant organic matter (POM) and released phytolith occur in the thin section. Not only generative, but vegetative indicators also occur; these imply elongate entires (ELO_ENT), elongate 


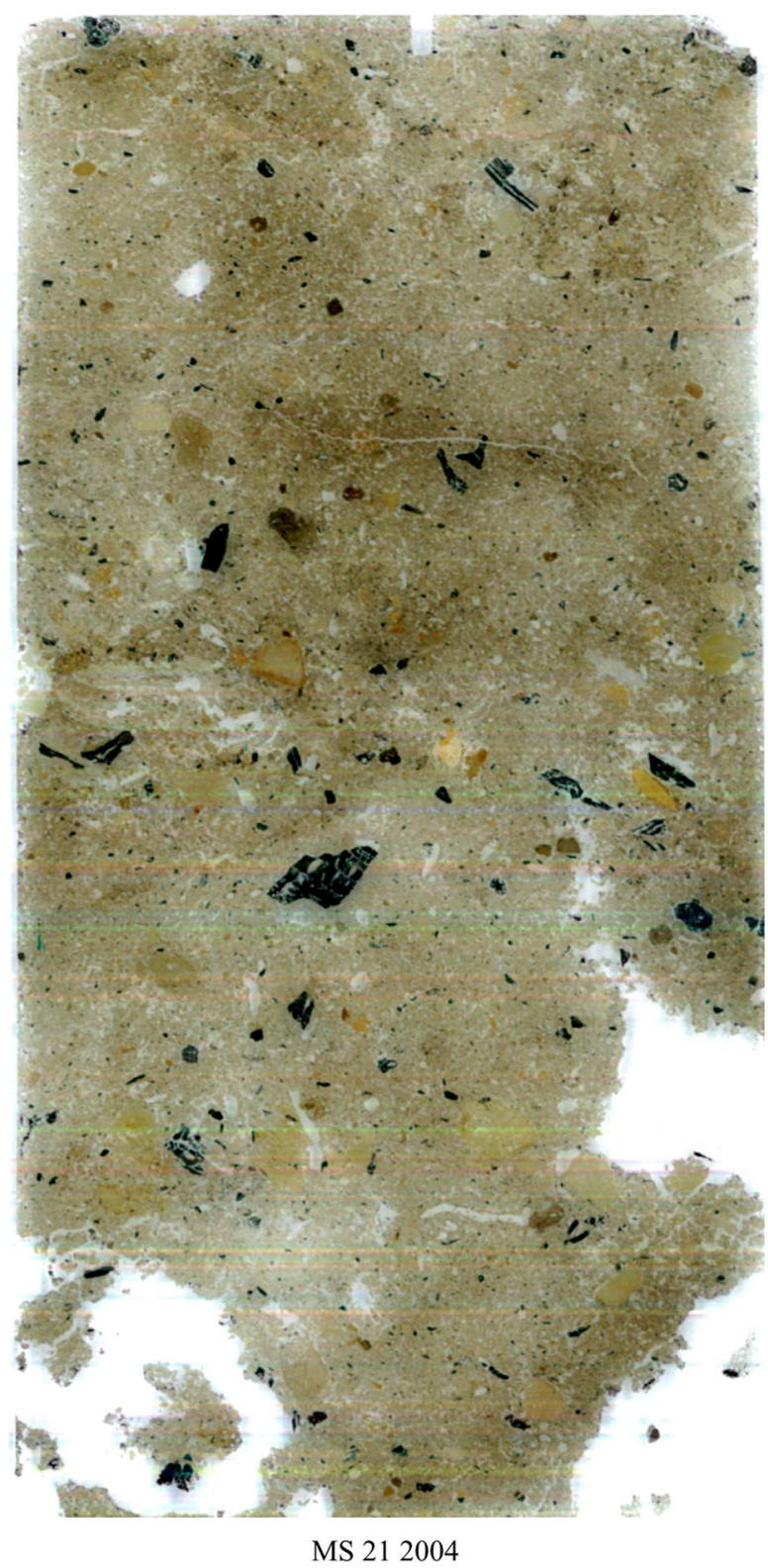

Fig. 7 General view of thin section MS 212004

sinuates (ELO_SIN), various trichome morphologies (TRI) and buliform cells (BULI) (ESM 2). The POM material is identified as cereal inflorescence cross-sections. The long tissue elements are more or less parallel; however, they are not straight, but show wavy pattern, indicating the secondary bioturbation and managing of the sediment material (Fig. 9a-d). This fragment later became mixed into the matter used for building the wall. The reason for this is that the 'base' of the wall was created from the general matrix of the site, which was highly compacted. This compacted general fill housed the posts, which supported the roof. The posthole was lined inside with fine plaster (clay), as sample MS7 2004 shows (Fig. 10). The plaster $\left(\mathrm{W}_{\mathrm{p}}\right)$ is very similar to that used for the flooring, thus suggesting a shared origin for the two materials. Sample
MS7 2004 also exhibits the compact wall 'base' $\left(\mathrm{W}_{\mathrm{s}}\right)$ in which various refuse elements are present. The compact wall-base can be considered slightly bioturbated, which is reflected by the distribution of plant opal assemblage in this layer. Plant opal particles are found partly released from the tissue, but tissue fragments in secondary position also occur. This latter undoubtedly refers to the bioturbation and disturbance of this material. The orientation of the phytoliths is random, does not mark any direction.

The final phase of the wall construction was the application of a fine yellow plaster, which was periodically renewed during the lifetime of the house (Figs. 11 and $12 \mathrm{a}$ and b; MS10 2004). In the case of this house it seems that the fine plaster layers were only applied from the inside. The application of this fine plaster by itself suggests concerns about 'hygiene', and this is further indicated by the sealing of the incorporated refuse elements of the wall 'base' from the living area.

As can be seen in the case of sample MS10 2004 (Fig. 11), the wall fragments are not in situ but in a secondary position surrounded by fallen-in debris. Sample MS 10 ' 04 will not be discussed in detail. The only importance of this sample is to show the fine wall plasterings (Fig. $12 \mathrm{a}$ and $\mathrm{b}$ ) that seem to be typical in some of the Vatya houses (Kovács and Vicze 2019). It clearly demonstrates that the plaster layers are very fine, compact and contain no anthropogenic inclusions. They show no sign of any kind of tempering, which is also true of the floor plasters. It is also evident that the first layer is slightly thicker than the rest of the renovation layers, which are only a couple of millimetres thick. The pore spaces are parallel to the main horizon, which is indicative of the smoothing effect with which the plaster was most likely applied. The number of replasterings is at least 5 on top of the initial plaster layer and they are $0.5-1.5 \mathrm{~mm}$ in thickness.

Mostly articulated phytoliths appear in the matrix of MS10 2004 in the form of silicified sheet elements, which are mostly not positioned in situ, but secondary processes of sediment management can be seen on them. Since the predominant morphotype is the elongate dendritic (ELO_DEN), which are found both in disarticulated and articulated form, the cereal indication is beyond doubt. The amount of POM is less than in sample MS 212004 and in accordance with this the exposition of the plant opal particles from the organic plant tissue is much better (Fig. $12 \mathrm{c}$ and d).

The detection and characterization of such walls are very important because such walls have not been described in detail earlier. Wattle and daub walls were considered typical of the Vatya Culture (Bóna 1982; Kovács 1984; Poroszlai 2000a). Although wattle and daub walls are also present at Százhalombatta-Földvár (Poroszlai 2000b; Poroszlai and Vicze 2004b; Vicze 2013), the recent excavation observations and the micromorphological analysis revealed that there is much more variation in terms of building and construction techniques than it was previously thought (Kovács and Vicze 2019). It was even 


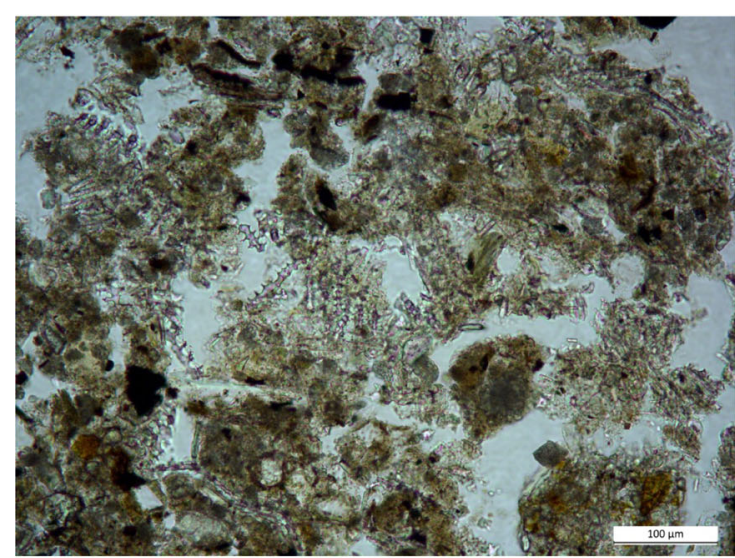

a)

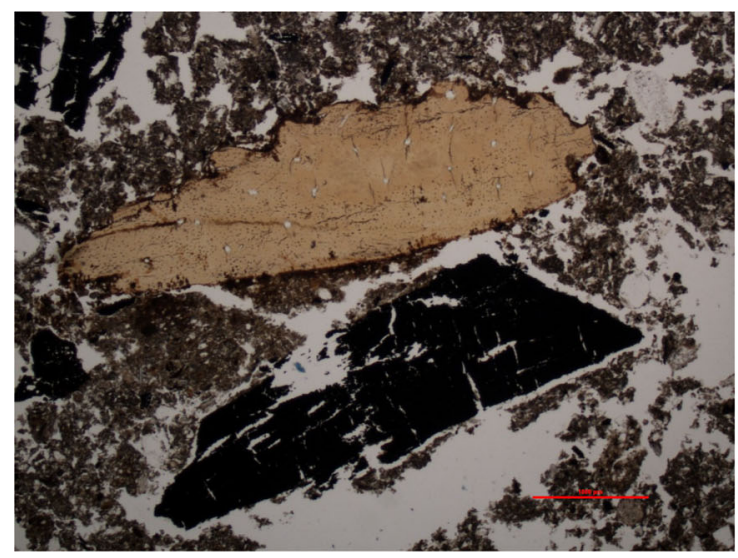

c)

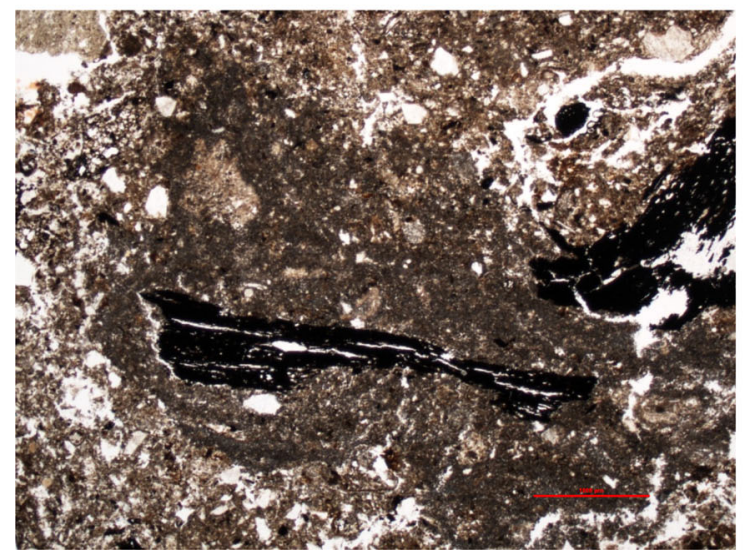

e)

Fig. 8 Sample MS7/1 2002: a disarticulated and relocated chaff indicator phytoliths in the unburnt debris layer $\left(\mathrm{C}_{\mathrm{ud}}\right)$, as well as b phytolith indicators of cereal chaff in anatomically sound position situated on the

proposed that there might be variation between the walls of the same house. Only systematic sampling and analysis of the wall fragments can shed more light on this assumption.

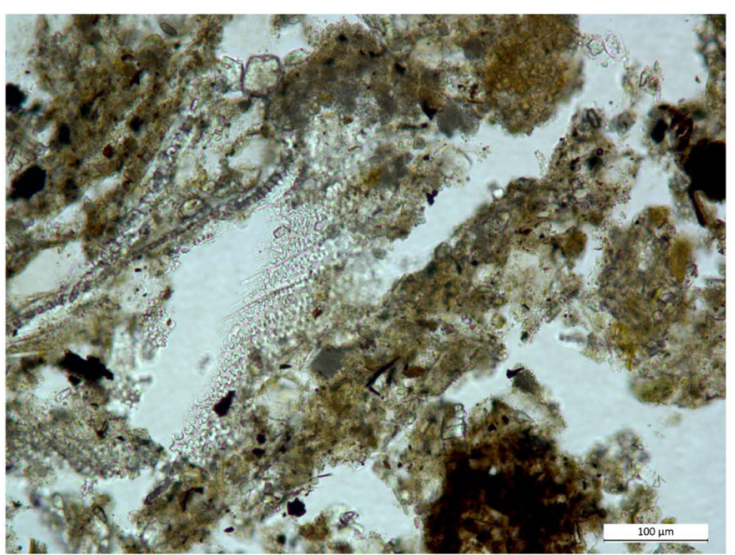

b)

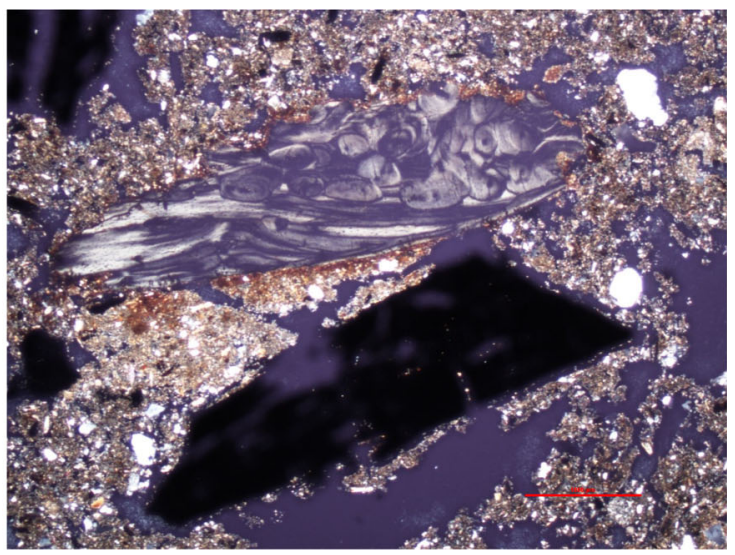

d)

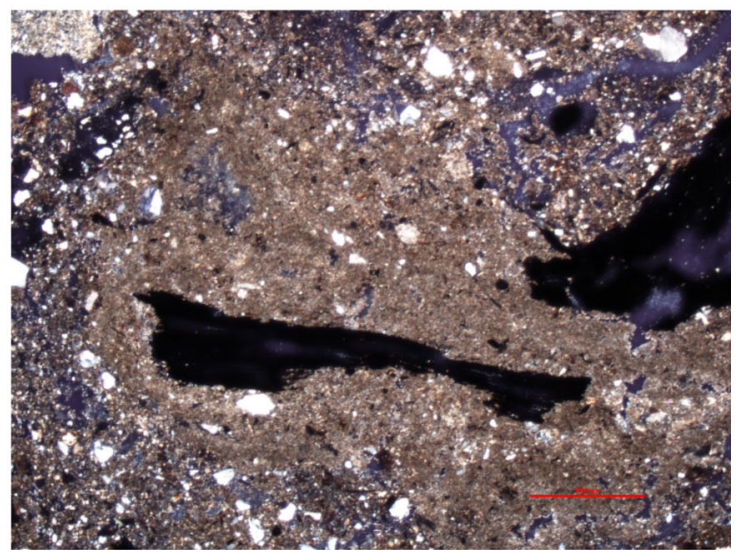

f)

top of the clay floor (C) (PPL). Sample MS21 2004: c, d bone fragment in secondary position (PPL; XPL); e, f ash fragment in secondary position (PPL; XPL) within the matrix of the wall structure

The separate plaster fragments lack any organic matter, no phytolith evidence, therefore no plant tempering could have been detected. However, the sediment material in which the 


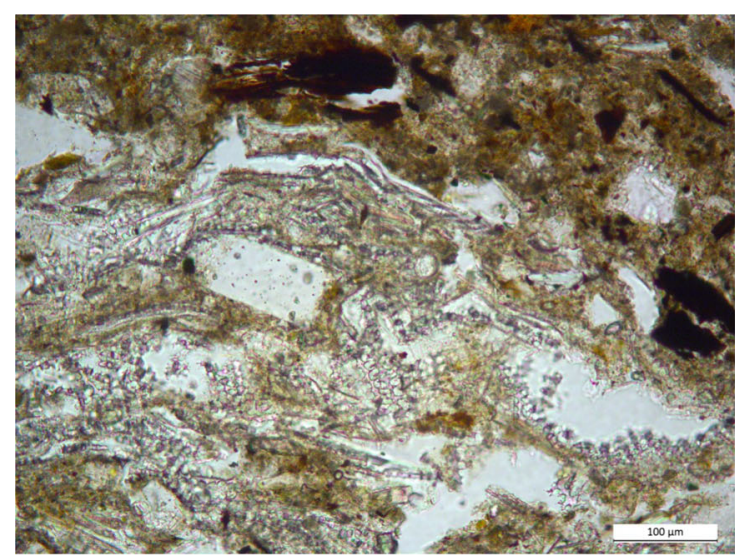

a)

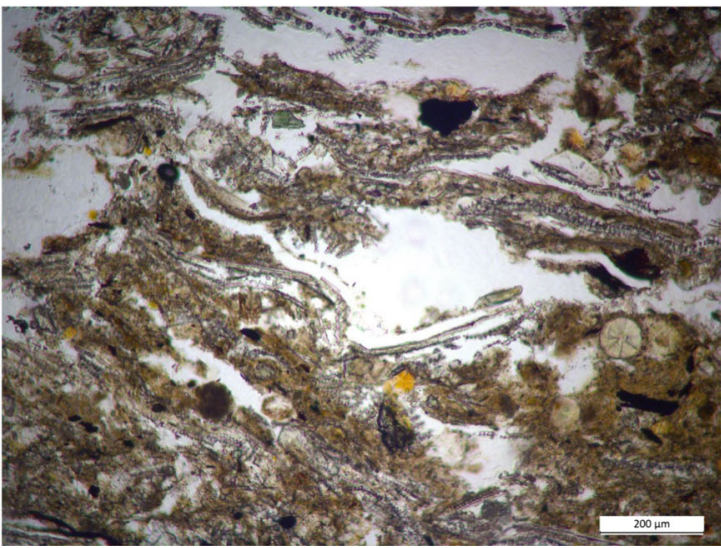

c)

Fig. 9 Sample MS21 2004 (wall structure): a, b disarticulated and released cereal chaff phytoliths showing post-depositional disturbance (PPL); c, d high abundance and variety of various plant sources within

plaster layers are embedded bear the above mentioned phytolith features.

\section{Hearth}

Hearths are the most obvious installations that we find in the Vatya houses and micromorphological investigations of them can reveal details that might be overlooked by other methods, such as field observations or content analysis. Furthermore, details of construction technique and building material can be investigated.

Two hearths have been unearthed in house ID 3147: one for each of the two building phases shown in Fig. $2 \mathrm{a}$ and $\mathrm{b}$. Both of them are situated in the northern area of the house close to the wall. They are almost at the same position, which clearly indicates the direct continuation of space use. Even though the floor has been renewed, using a different technique (from earthen floors to plaster floor), the location of the hearth

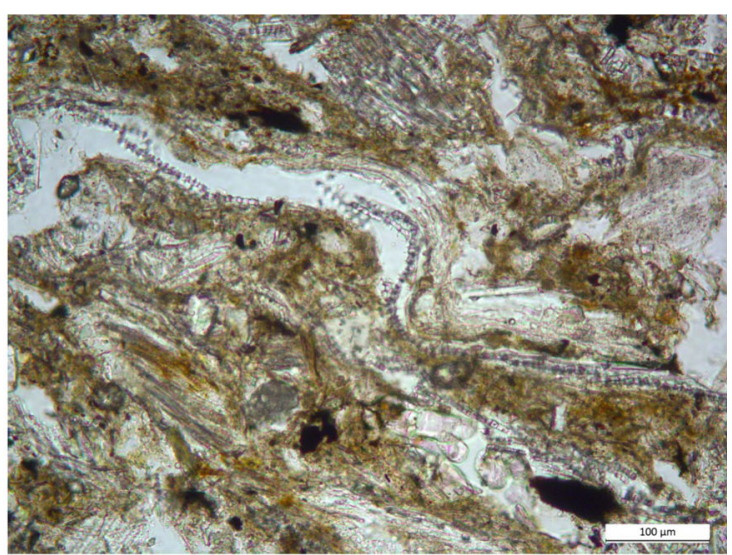

b)

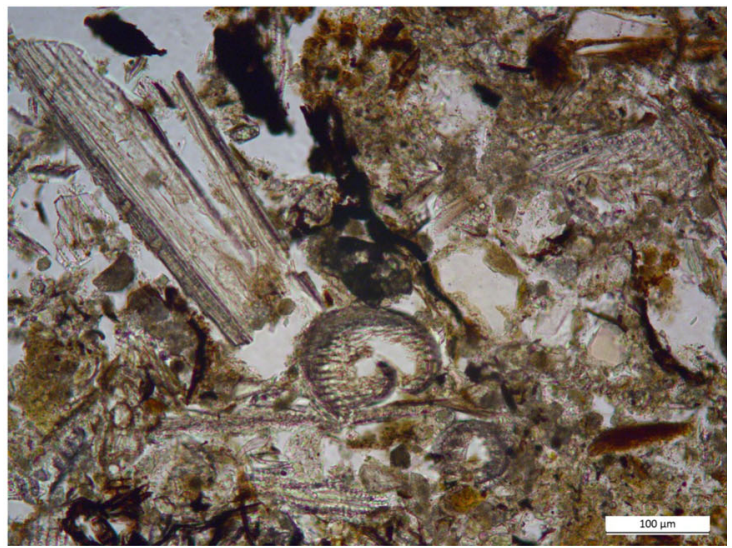

d)

the matrix of the wall structure; cereal chaff cross-section nicely reveals its internal anatomical structure on microphotograph (d) (PPL)

remained the same. The later hearth partially destroyed the older one, as indicated on the plan (Fig. 2 a and b). Only the wall of the later hearth was subject to micromorphological investigation (sample MS20 2004). Unfortunately, the content of the hearth was not sampled, thus, it is impossible to make conclusions regarding the fuel type. However, if we propose that the ash in the southern half of the house (MS 13 2004) logically was originated from the house's own heart then based on the ash layers detected on the plaster floor surface in sample MS13 2004 we can suggest that wood (indicated by the charcoal fragments), grasses (indicated by the burnt phytoliths that are most characteristic of grasses) and possibly dung (in forms of phytoliths and faecal spherulites) were also involved in the firing process.

Sample MS20 2004 is composed of four micro-layers ( $\mathrm{W}_{\mathrm{hc} 1}$ to $\mathrm{W}_{\mathrm{hc} 4}$; Table 1 ). The macroscopic observations during the excavation revealed that the hearth of the 2 nd phase was renovated several times-suggesting regular 


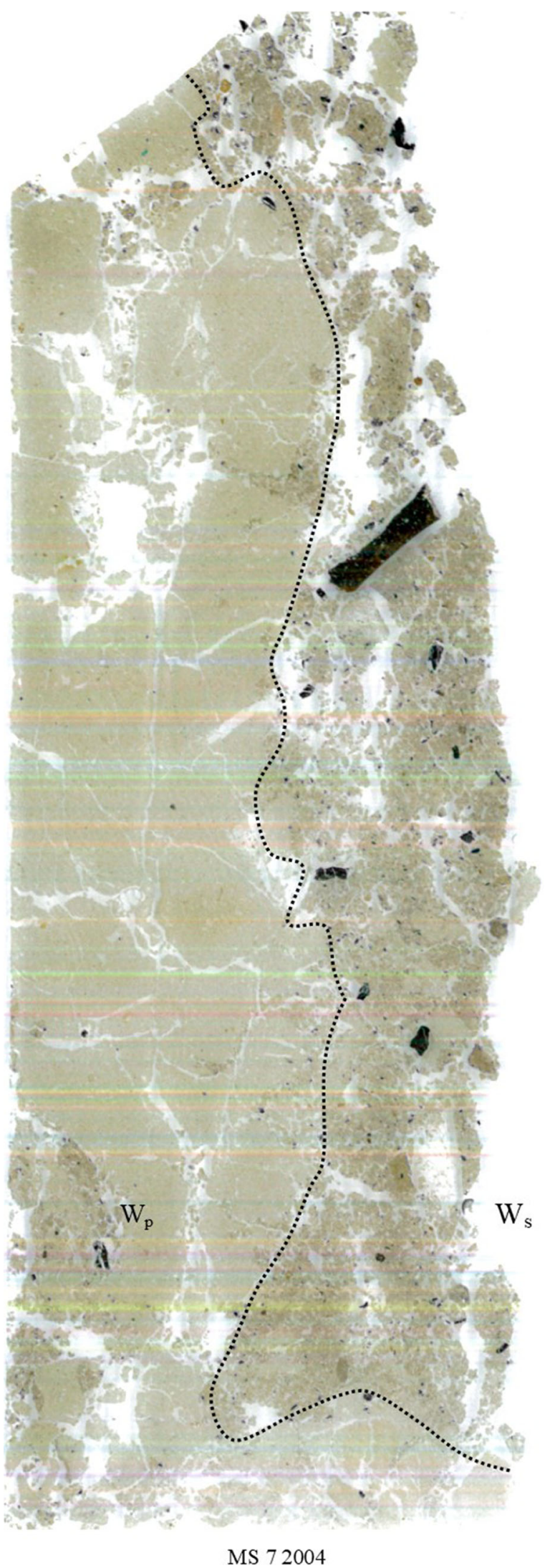

Fig. 10 General view of thin section MS 72004 maintenance-which could not be captured in one sample. So, only part of the hearth wall will be investigated here. Fine structured, compact, clay material was used to create the hearth wall ( $\mathrm{W}_{\mathrm{hc} 2}$ to $\mathrm{W}_{\mathrm{hc} 4}$; Table 1) (Fig. $13 \mathrm{a}$ and b), just as was used for the wall or floor plasters. However, there is a significant difference to wall/floor plasters, which is the larger amount of organic matter (in forms of burnt-out plant voids, retaining phytoliths and charred organic material). ' $W_{h c l}$ ' is different once compared with the other horizons. It contains more anthropogenic inclusions such as daub and pottery

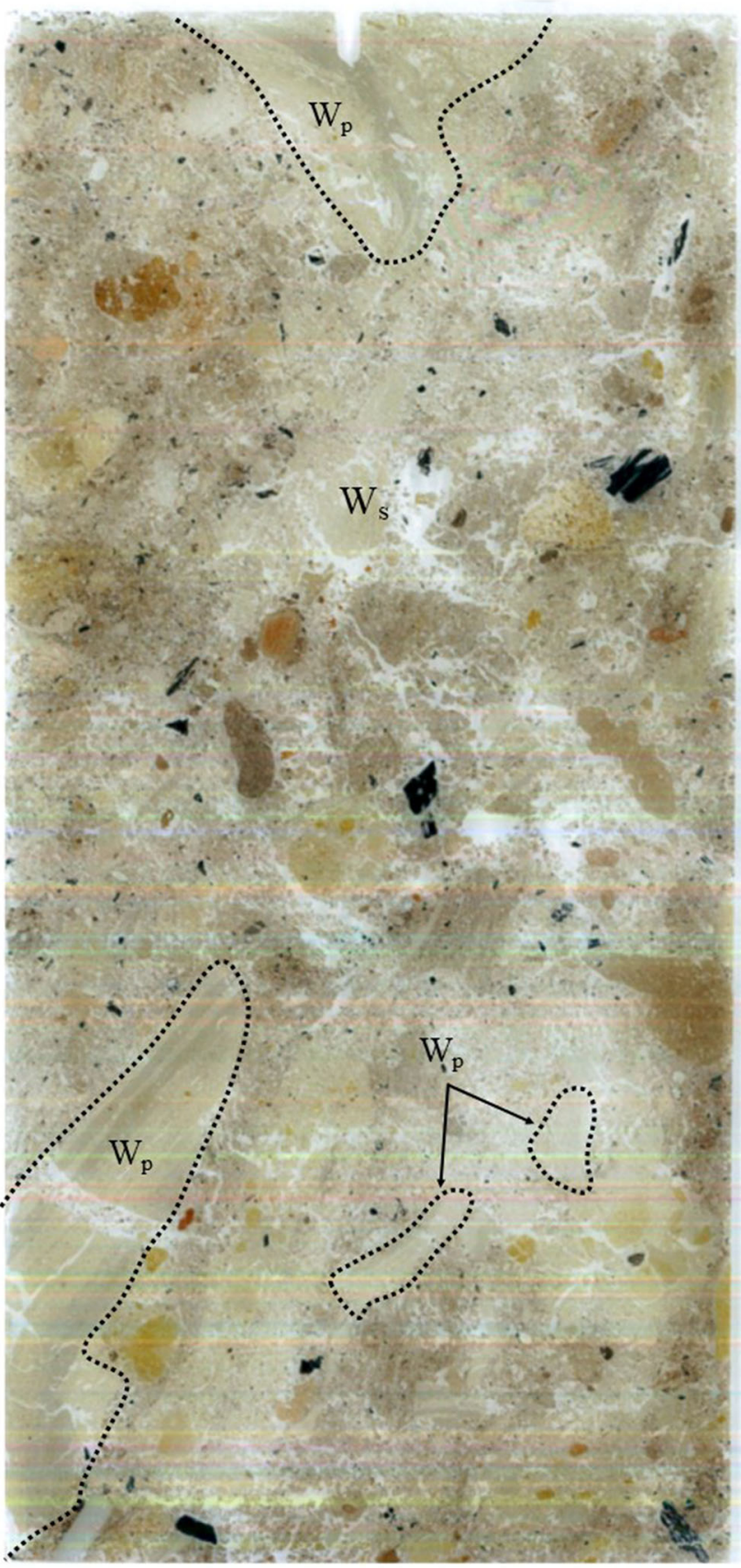

MS 102004

Fig. 11 General view of thin section MS 102004 


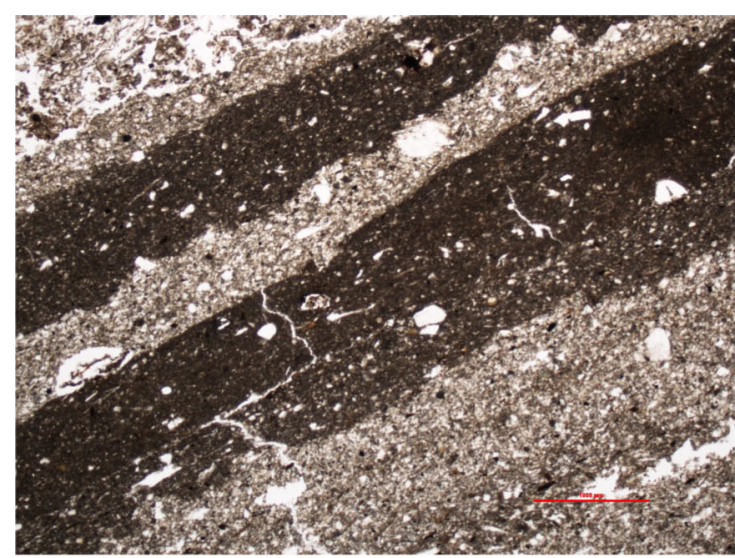

a)

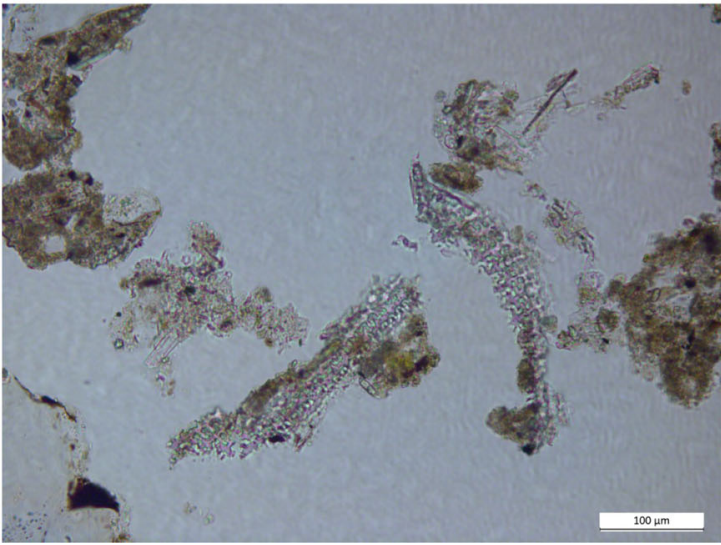

c)

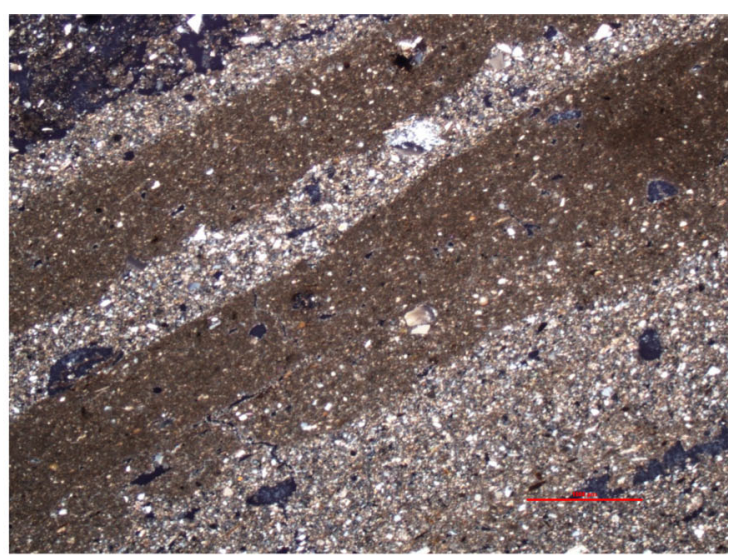

b)

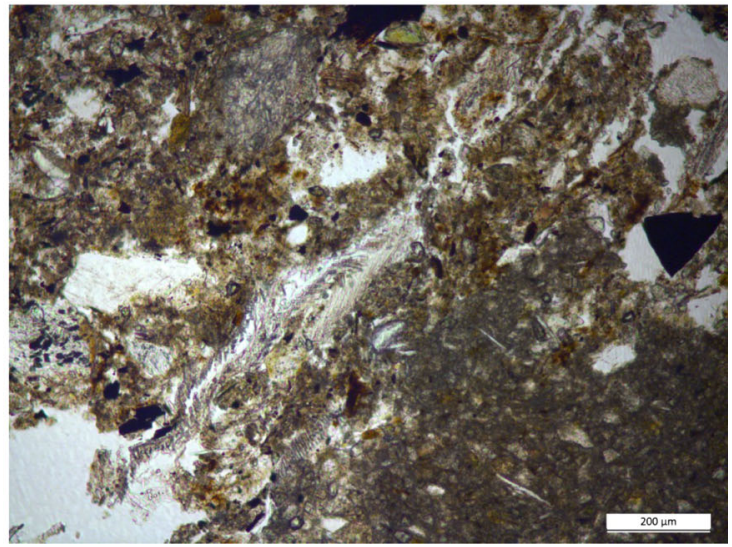

d)

Fig. 12 a, b Series of wall plasterings in sample MS10 2004 (PPL, XPL); c cereal chaff fragment positioned in a void (PPL); d plant material showing the direction of plastering (PPL)

fragments (Fig. $13 \mathrm{c}$ and d). Only a small part of this matter is available for analysis therefore it is problematic to ascertain its relation to the undelaying horizon and to the hearth as well. It is more likely that this horizon is not another wall renovation, but something else.

The abundance of organic matter in the hearth wall material suggests that it was used as temper and the rest of the inclusions might be indicative of the refuse elements around the hearth, which became mixed into the material during the renovation phase. Cereal chaff, which is a continuously returning element on the tell material could have been also identified among the vegetal and organic temper material. The majority of the clay matter used during the construction was rather 'clean' and the small amount of anthropogenic inclusions suggests that they were not used intentionally.

\section{Conclusions}

Microscopic analysis not only confirmed the initial field impressions but also revealed additional details. The field observation of possible earthen floors was confirmed and numerical data could be added. The earthen floor was not the result of a single occupation event but the result of several renovation phases (Fig. 3). Five earthen floors could be investigated due to the micromorphological sampling. No floor build-up was detected between the earthen floors, so the range of activities ongoing could not be assessed based on the microscopic investigation. However, this shows the need for cleanliness as refuse/floor build-up was removed.

During the lifetime of the house a major change took place regarding the floor building practice. During the 2 nd building phase, the previously practised earthen floor renovation stopped and the whole floor was renewed with yellow clay to a thickness of approximately $3 \mathrm{~cm}$. In terms of the use of space, regular cleaning and maintenance is clearly detectable throughout the life span of the house, except for the last occupation surface just before it was abandoned. It raises the question of the original thickness of the earthen floors. We propose that the original thickness of the earthen floors was much thicker, and what we see here is just part of the original floor. This is what we could prove during the analysis of 


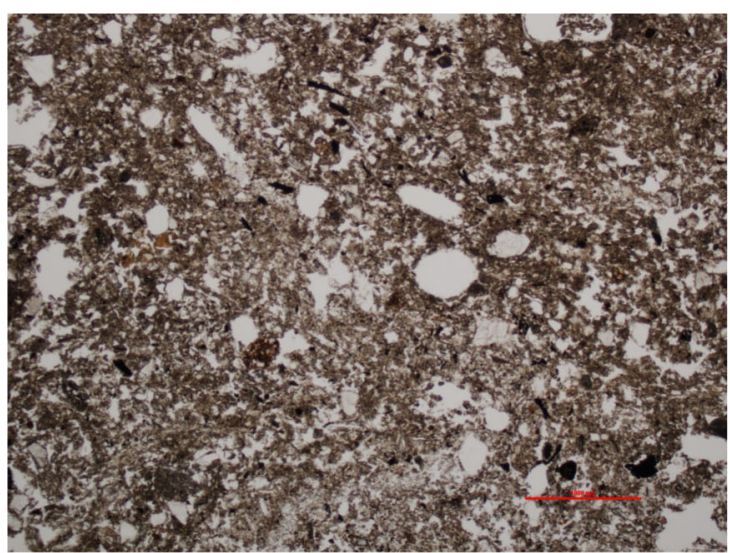

a)

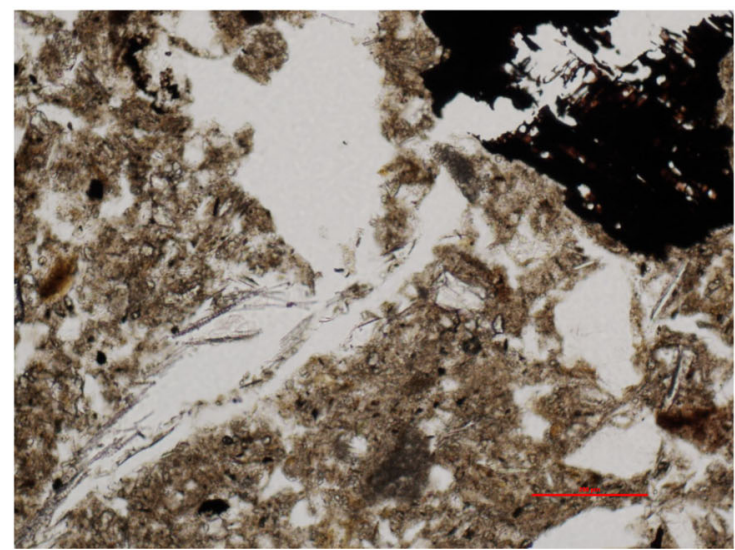

c)

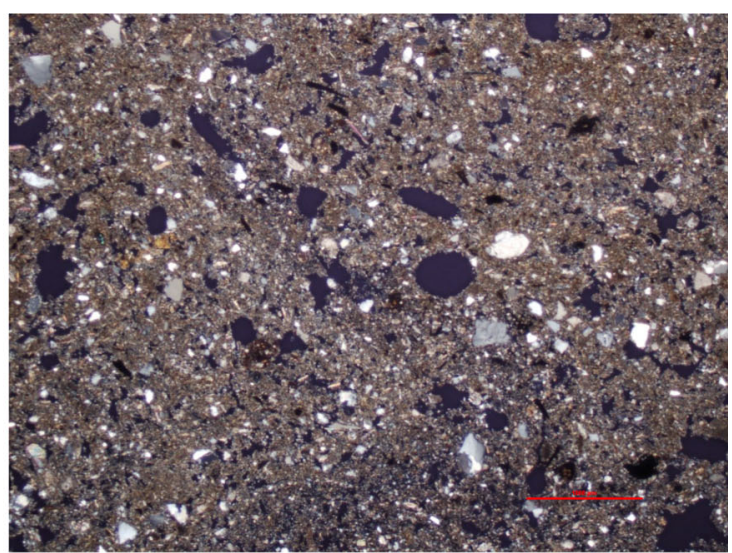

b)

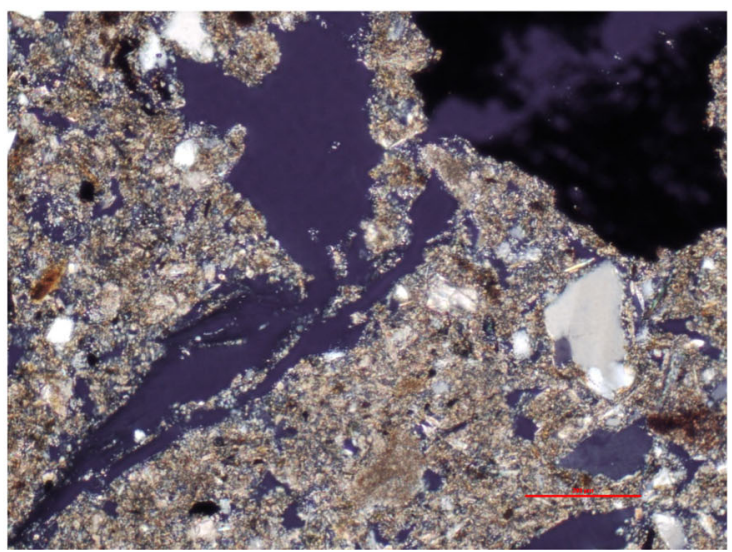

d)

Fig. 13 Sample MS20 2004: a, b matrix of the hearth wall in (PPL, XPL); c, d matrix of the hearth wall with organics and anthropogenic inclusions (PPL, XPL)

various clay floors of the site. Clay floors were periodically renovated and renewed. What we see in those cases is that a series of thin floor layers are topped with a ca. $3 \mathrm{~cm}$ thick floor (being the last one in the series) (Kovács and Vicze 2019). Although house 3147 is the only house so far that exhibited a series of earthen floor renewals, based on the clay floor renewal practice we propose that earthen floors were treated the same way as well. Further analysis of houses will hopefully help to better understand earthen floor building techniques at the site.

There is a clearly visible pattern between the northern and southern areas of the house in case of both of the two building phases: the southern area contains higher amounts of ash and charcoal. Data shows that during the first phase (earthen floors) the floor matter contained larger amounts of ash and charcoal in the southern area, while during the second phase (clay floor) it was spread on top of the clay floor. The hearth area is likely to have more heat, therefore reduced dampness, while further from there some action had to be made for benefit. Also, the hearth area might have been kept cleaner and the ash from the hearth rake-out would have been beneficial for other areas for the disinfectant and/or absorbent effect of ash.
The slightly higher rates of anthropogenic inclusions, found in the southern area, and their greater variation also suggests that the hearth area (northern part) was kept cleaner.

The wall of the house revealed new techniques applied during wall construction. The previously believed wattle and daub walls are not the only ways of wall preparation. The compacted general fill material of the settlement was used to create the foundation of the wall that incorporated the posts, and apparently only the inner side of the wall was plastered to seal the living area. Continuous re-plasterings of the walls reveal that regular maintenance was practiced. Fine wall plasters and floors share common features. All of them are fine, compact and lack vegetal tempering.

The hearth of the second phase of the house was also sampled. The hearth was renovated several times, showing regular maintenance and stayed almost at the same location during both phases. Although no micromorphological sample was taken from the inside of the hearth, the deposited ash inside the southern part of the house (likely to be derived from the hearth) indicated that wood, grasses and possibly even dung was used for firing. The wall plaster of the hearth is also similar to the floor plasters, but higher amount of vegetal addition could be observed. 
Overall, it has to be realized that construction was well thought out and material of different quality was applied to the various elements (for example fine, 'clean' matter for inner wall and floor plaster vs. general fill with waste fragments for the wall foundation). Regular maintenance and cleaning, together with remnants of firing, were identifiable. The absence of microscopic evidence of craftwork, metalwork or any other activity (e.g. animal keeping) (that is likely to survive cleaning) reveals that the building was used for housing. This correlates well with the archaeological observations as well.

The above stated results have important implications in both methodology and interpretation for archaeology. Foremost is the level of detail that we have a chance to look into prehistoric life, from the macro- to the microscopic level. This affects our understanding of decisions made in prehistory, such as choice of raw material or activities like maintenance of floors, walls within households.

Further, these analyses allow the archaeologists to ask entirely new questions or to think about aspects in a way that has never been done before. For example, some of these vexing questions now are: How was it possible at that time to achieve the extent of cleanness of the general matrix, as seen in the case of the subjected house? What kind of processes and techniques were used for this purpose that was known to and applicable by the Bronze Age craftsmen? It is clear that they had full knowledge of the quality and the composition of the general fill of the site that surrounded them. Furthermore, they seem to have had full control over the required property of the raw material for different purposes (see the difference in particle sizes in the raw material used for the earthen floors and that of the inner-wall). Similarly, what was the purpose behind the choice for using and treating the general fill of the site instead of bringing the commonly used clean clay? This is even more interesting knowing that the earthen floor of this house had seen several renovations from the same material suggesting a long use-life. It has been laid down then after some use it has been scraped clean for a new layer of the same material for four times, at least in certain areas of the house. This repetition of scraping and spreading new layer on a floor surface has been noted and documented with yellow clay floors as well (see Kovács and Vicze 2019), which infers a prevailing knowhow and routine. The recognition and discovery of this series of action in itself is significant as it could not have been documented if it were not for the soil micromorphology and phytolith analyses. During excavation, laminations within floors could be recognized on occasion but their exact number and their construction details would completely elude archaeology. However, the implications of these observations are even more important as they provide new insights into prehistoric daily life, customs and decisionmaking. Similar regularity was observed in the case of house wall plastering. Here, the possibility to quantify these events and thus be able to assess their regularity again sheds new light onto the routines of this prehistoric society. Both abovementioned observations suggest on the one hand the presence of a consistent and regular maintenance of houses. On the other a deliberate choice between construction materials can be detected, the significance of which needs further studies.

The different treatment of the clay raw material is not a surprise and not a novel information, however its fine scale quantification is. Thanks to the avenue opened by the microscopic level of examination there is a possibility now to finetune and even categorize the quality and composition of the prepared construction materials. It was possible to show that clay in its purest form was regularly used for re-plastering walls. The extremely thin layers of $0.5-1.5 \mathrm{~mm}$ could be reached only if the clay was diluted to an extent of liquid form, then applied to the walls. Whereas, probably the same clay resource was used for laying the floors in a state that was close to its natural occurrence. The case of the renovated hearth within house ID 3147 is very interesting. The raw material used for its re-building contains an amount of naturally present phytoliths that suggests a secondary source. It is plausible that a man-made depo of clay was established nearby the settlement or within it that could be used for small-scale renovations. Further examples of clay treatment, such as the variability within the production of daub, lie outside the scope of this study.

Finally, it can be concluded that, there are more questions raised at the end of this investigation, than we started with. Nevertheless, it was possible to document deliberate choice of raw material. In the case of house ID 3147 , the general matrix of the site fill was chosen for the first floor and the inner-wall, over the regularly used clean yellow clay. This choice, however, opened new possible line of inquiry about the technological knowhow and the routines of the everyday life of the Bronze Age society at Százhalombatta-Földvár. Our aim to detect choice of material with the help of archaeological thin section soil micromorphology and phytolith analyses can be deemed successful. Yet, we presume that the extent of their usefulness has just started to be recognized. In our opinion there is a wide avenue for further research.

Funding Open access funding provided by Szent István University. The work of Ákos Pető was funded by the János Bolyai Research Scholarship of the Hungarian Academy of Sciences, as well as by the National Research, Development and Innovation Office [grant number: PD 124607].

Open Access This article is licensed under a Creative Commons Attribution 4.0 International License, which permits use, sharing, adaptation, distribution and reproduction in any medium or format, as long as you give appropriate credit to the original author(s) and the source, provide a link to the Creative Commons licence, and indicate if changes were made. The images or other third party material in this article are included in the article's Creative Commons licence, unless indicated otherwise in a credit line to the material. If material is not included in the 
article's Creative Commons licence and your intended use is not permitted by statutory regulation or exceeds the permitted use, you will need to obtain permission directly from the copyright holder. To view a copy of this licence, visit http://creativecommons.org/licenses/by/4.0/.

\section{References}

Anderson PC, Chabot J, van Gijn A (2004) The functional of 'glossy' Canaanean blades and the near eastern Treshing sledges. J Mediterr Archaeol 17(1):87-130

Anderson PC, Georges J-M, Vargiolu R, Zahouani H (2006) Insights from a tribological analysis of the tribulum. J Archaeol Sci 33:1559-1568

Ball TB (1992) Phytolithy morphometries: the use of image analysis for morphologie and systematic study of various grass phytoliths (Bouteloua, Panicum, Zea, and Triticum). Unpublished PhD dissertation, Brigham Young University

Ball TB, Gardner JS, Brotherson JD (1996) Identifying phytoliths produced by the inflorescence bracts of three species of wheat (Triticum monococcum L., T. dicoccon Schrank., and T. aestivum L.) using computer-assisted image and statistical analyses. J Archaeol Sci 23(4):619-632

Ball TB, Gardner JS, Anderson N (1999) Identifying inflorescence phytoliths from selected species of wheat (Triticum monococcum, T. dicoccon, T. dicoccoides, and T. aestivum) and barley (Hordeum vulgare and $\mathrm{H}$. spontaneum) (Gramineae). Am J Bot 86(11):1615-1623

Ball TB, Vrydaghs L, Mercer T, Pearce M, Snyder S, Lisztes-Szabó Z, Pető Á (2017) A morphometric study of variance in articulated dednritic phytolith wave lobes within selected species of Triticeae and Aveneae. Veg Hist Archaeobotany 26(1):85-97

Banerjea RY, Bell M, Matthews W, Brown A (2013) Application of micromorphology to understanding activity areas and site formation processes in experimental hut floor. Archaeol Anthropol Sci 7:89-112

Blinnikov M (2008) Phytolith analysis in limited paleoenvironmental contexts: AAA (Artic, alpine or aquatic). 7th International Meeting on Phytolith Research - 4th Southamerican Meeting on Phytolith Research. Book of Abstracts. Mar del Plata, Argentina: Universidad Nacional Mar del Plata. 4. 4

Bóna I (1982) Alpár bronzkori rétegei. In: Bóna I, Nováki Gy (Szerk.) Alpár bronzkori és Árpád-kori vára. Cumania 7:17-117

Bullock P, Federoff N, Jongerius A, Stoops G, Tursina T and Babel U (1985) Handbook for soil thin section description. Waine Research Publications, Wolverhampton

Canti MG (1998) The micromorphological identification of faecal spherulites from archaeological and modern materials. J Archaeol Sci 25: 435-444

Courty MA, Goldberg P, Macphail RI (1989) Soils and micromorphology in archaeology. Cambridge University Press, Cambridge

De Paepe P, Rutten K, Vrydaghs L, Haerinck E (2003) Petrographic, chemical and phytolith analysis of late Preislamic ceramic from ed-Dur, Um el-Kawein (U.A.E.), in: D. Potts, H. Hasan Al Naboodah and P. Hellyer (Eds.), Archaeology of the United Arab Emirates. Proceedings of the First International Conference on the Archaeology of the United Arab Emirates. Trident Press, London, 207-229

Devos Y, Vrydaghs L, Degraeve A, Fechner K (2009) Palaeoenvironmental research on the site of rue the Dinant (Brussels): an interdisciplinary study of dark earth. Catena 78:270-284

Devos Y, Nicosia C, Vrydaghs L, Modrie S (2013a) Studying urban stratigraphy: dark earth and a microstratified sequence on the site of the Court of Hoogstraeten (Brussels, Belgium). Integrating archaeopedology and phytolith analysis. Quat Int 315:147-166

Devos Y, Wouters B, Vrydaghs L, Tys D, Bellens T, Schryvers A (2013b) A soil micromorphological study on the origins of the early medieval trading Centre of Antwerp (Belgium). Quat Int 315:167-183
Devos Y, Nicosia C, Vrydaghs L, Speleers L, van der Valk J, Marinova E, Claes B, Albert RM, Esteban I, Terry B, Court-Picon M, Degraeve A (2017) An integrated study of dark earth from the alluvial valley of the Senne river (Brussels, Belgium). Quat Int 460:175-197

Devos Y, Hodson MJ, Vrydaghs L (2020) Auto-fluorescent phytoliths: a new method for detecting heating and fire. Environ Archaeol:1-18. https://doi.org/10.1080/14614103.2020.1777056

Dickinson WC (2000) Integrative plant anatomy. Harcourt Academic Press, Burlinton, Massachusetts

Fishkis O, Ingwersen J, Streck T (2009) Phytolith transport in sandy sediment: experiments and modelling. Geoderma 151:168-178

Fishkis O, Ingwersen J, Lamers M, Denysenko D, Streck T (2010a) Phytolith transport in soil: a field study using fluorescent labelling. Geoderma 157:27-36

Fishkis O, Ingwersen J, Lamers M, Denysenko D, Streck T (2010b) Phytolith transport in soil: a laboratory study on intact soil cores. Eur J Soil Sci 61(4):445-455

French CAI (2003) Geoarchaeology in action: studies in soil micromorphology and landscape evolution. Routledge, London

Frisnyák SJ, Futó L, Göőz G, Kormány K, Moholi M, Erdős P, SüliZakar I (1977) Magyarország földrajza. Tankönyvkiadó, Budapest

Füleky G (2005) Soils of the bronze age tell in Százhalombatta. In: Poroszlai I, Vicze M (eds) Százhalombatt archaeological expedition - SAX: report 2 - field seasons 2000-2003. Emergence of European Communities, Archaeological Reports, Matrica Museum, Százhalombatta, pp 89-110

Goldberg P (1992) Micromorphology, soils and archaeological sites. In: Holliday VT (ed) Soils in archaeology. Smithsonian Institution Press, Washington and London, pp 145-167

Gyalog L (Szerk/ed) (2005). Magyarország Földtani Térképe [Geological Map of Hungary]: L-34-14 (Érd-Bicske) (Császár G, Csereklei E 2000; Budai T. 2004; Kaiser M 2004 eds) fedett földtani térképek [L-34-14 Érd-Bicske surface geological map; 1:10.000]. In: Magyarázó Magyarország fedett földtani térképéhez [Explanatory text to the surface geological map of Hungary]. Magyar Állami Földtani Intézet, Budapest, 189

Hakbijl T (2002) The traditional, historical and prehistoric use of ashes as an insecticide, with an experimental study on the insecticidal efficacy of washed ash. Environ Archaeol 7:13-22

Haraszty Á (szerk/ed) 1979. Növényszervezettan és növényélettan. Tankönyvkiadó, Budapest

ICPT - International Commitee for Phytolith Taxonomy (2019). International Code for Phytolith Nomenclature (ICPN) 2.0. Annals of Botany X(X), 1-11. [doi: https://doi.org/10.1093/aob/mcz064]

Kalmár J (2005) Geological background of the tell-type site from Százhalombatta. In: Poroszlai I, Vicze M (eds) Százhalombatt archaeological expedition - SAX: report 2 - field seasons 2000-2003. Emergence of European Communities, Archaeological Reports, Matrica Museum, Százhalombatta, pp 81-87

Karkanas P, Bar-Yosef O, Goldberg P, Weiner S (2000) Diagenesis in prehistoric caves: the use of minerals that form in situ to assess the completeness of the archaeological record. J Archaeol Sci 27:915-929

Korstanje MA, Babot MDP (2007) Microfossils characterization from south Andean economic plants. In: Madella M, Zurro D (eds) Plants, people and places, recent studies in phytolith analysis. Oxbow Books, Oakville, pp 41-72

Korstanje MA, Babot MDP (2008) Matices Interdisciplinarios en Estudios Fitolíticos y de Otros Microfósiles. Oxford: British Archaeological Reports, International Series 1870

Kovács T (1984) Die Vatya-Kultur, In Tasić, N. (Ed.), Kulturen der Frühbronzezeit das Karpatenbeckens und Nordbalkans, Beograd 219-233

Kovács G (2005) Reconstruction of the former environment and investigation of human activity at Százhalombatta-Földvár bronze age tell settlement. In: Poroszlai I, Vicze M (eds) Százhalombatt archaeological expedition - SAX: report 2 - field seasons 2000-2003. 
Emergence of European Communities, Archaeological Reports, Matrica Museum, Százhalombatta, pp 125-134

Kovács G (2009) Geoarchaeological investigation of SzázhalombattaFöldvár Bronze Age tell settlement in Hungary, Unpublished $\mathrm{PhD}$ thesis, University of Cambridge, Department of Archaeology, UK

Kovács G (2013) Micromorphology of the household at SzázhalombattaFöldvár Bronze Age tell settlement, Hungary, In: Madella, M, Kovács, G, Berzsényi, B and Briz, I (Eds.) The archaeology of household, Oxbow books, 179-216

Kovács G, Vicze M (2019) Építéstechnikai megfigyelések lehetőségei vékonycsiszolatok segítségével Százhalombatta-Földvár lelőhelyen (Possibilities of construction technical observations using thin section soil micromorphology at Százhalombatta-Földvár site). In: Vicze M, Kovács G (Eds.), M $\mathrm{MO} \Sigma \mathrm{X}$. Öskoros Kutatók X. Összejövetelének konferenciakötete - Öskori technikák, őskori technológiák. Százhalombatta, 2017. április 6-8. Százhalombatta 151-183

Kreiter A, Pető Á, Pánczél P (2013) Materializing tradition: ceramic production in Early and Middle Neolithic Hungary, in: Bánffy E (Ed.), The Early Neolithic of the Danube-Tisza Interfluve. BAR IS 2584, Central European Series 7, Archaeopress, Oxford. 127-140

Kreiter A, Riebe DJ, Parkinson WA, Pető Á, Tóth M, Pánczél P, Bánffy E (2014) Unique in its chaîne opératoire, unique in its symbolism: undressing a figurine from the 6th millennium BC Körös culture, Hungary. J Archaeol Sci 44:136-147

Kristiansen K (2000) The emergence of European Communities: household, settlement and territory in Later Prehistory (2300-300 BC), In: Poroszlai I, Vicze M (Eds), Százhalombatta Archaeological Expedition, Annual Report I, 7-12

Lippi MM, Gonnelli T, Pallecchi P (2011) Rice chaff in ceramics from the archaeological site of Sumhuram (Dhofar, southern Oman). J Archaeol Sci 38(6):1173-1179

Madella M, Kovács G, Berzsényi B, Briz i Godina, I. 2013. The Archaeology of Households. Oxbow Books, Oxford, UK, 288

Marosi S, Somogyi S (1990) Magyarország kistájainak katasztere I-II. MTA Földrajztudományi Kutató Intézet, Budapest, 1023

Matthews W (1995). Micromorphological characteristics of occupation deposits and microstratigraphic sequences at Abu Salabikh, Southern Iraq. In: Barnham A J, Macphail, R I (Eds.) Archaeological sediments and soils: analysis, interpretation and management. Institute of Archaeology, University College, London. 41-76

Metcalfe CR (1960) Anatomy of the monocotyledons, vol I. Clarendon Press, Oxford, Gramineae

Milek K (2000) Early medieval house floors in Britain and Iceland. Conference paper presented at the Soil Micromorphology in Archaeology workshop, Cambridge

Milek K (2006) 'Houses and households in Early Icelandic Society: Geoarchaeology and the interpretation of social space'. Unpublished $\mathrm{PhD}$ thesis. University of Cambridge

Miller Rosen A (1992) Preliminary identification of silica skeletons from near eastern archaeological sites: an anatomical approach. In: Rapp G, Mulholland SC (Eds.) Phytolith systematics, Emerging issues. Plenum Press, New York, pp 129-147

Murphy CP 1986. Thin section preparation of soils and sediments. A. B. Academic, Berkhamsted

Nicosia C, Canti MG (2017) Chaff. In: Nicosia C, Stoops G (eds) Archaeological soil and sediment micromorphology. Wiley Blackwell, Oxford, pp 137-140

Nicosia C, Stoops G (eds) (2017) Archaeological soil and sediment micromorphology. Wiley Blackwell, Oxford

Parry DW, Smithson F (1966) Opaline silica in the inflorescens of some British grasses and cereals. Ann Bot 30:525-538

Pécsi M (1967) A Dunai Alföld. Akadémia Kiadó, Budapest

Pető Á, Vrydaghs L (2016) Phytolith analysis of ceramic thin sections. First taphonomical insights gained through experiments with vegetal tempering of bread wheat (Triticum aestivum L. ssp. aestivum) organs. In: Sibbesson E, Jervis B, Coxon S (eds) Insight from innovation: new light on archaeological ceramics, Southampton monographs in archaeology, new series 6. Highfield Press, St. Andrews, UK, pp 57-73

Piperno DR (1988) Phytoliths. An archaeological and geological perspective. Academic Press, London

Piperno DR (2006) Phytoliths: a comprehensive guide for archaeologists and paleoecologists. AltaMira, Lanham, MD

Poroszlai I (2000a) Die Grabungen in der Tell-Siedlung von BölcskeVörösgyürü (Kom. Tolna) (1965-1967). Acta Archaeologica Hungaricae 51:111-145

Poroszlai I (2000b) Excavation campaigns at the Bronze Age tell site at Százhalombatta-Földvár, I. 1989-1991; II. 1991-1993. In: Poroszlai I and Vicze M (Eds.) SAX, Százhalombatta Archaeological Expedition, Annual Report 1-Field Season 1998. 'Matrica' Museum, Százhalombatta 13-74

Poroszlai, I., Vicze, M. 2004a. Methodological background of a modern tell excavation in Hungary, in: Bátora J, Furmánek V, Veliacik L (Eds.) Einflüsse und Kontakte Alteuropaischer Kulturen. Festschrift für Jozef Vladár zum 70. Geburtstag. Nitra 231-240

Poroszlai I, Vicze M (2004b) Százhalombatta, Földvár (MRT 7. k. 27/2 lelőhely). In: Kisfaludy J (Szerk.) Régészeti kutatások Magyarországon 2003 / Archaeological Investigations in Hungary 2003. 290-293

Portillo M, García-Suárez A, Klimowicz A, Barański MZ, Matthews W (2019) Animal penning and open area activity at Neolithic Çatalhöyük, Turkey, Journal of Anthropological Archaeology, Volume 56

Rovner I (1971) Potential of opal phytoliths for use in paleoecological reconstruction. Quat Res 1:343-359

Shilito LM (2011) Grains of truth or transparent blindfolds? A review of current debates in archaeological phytolith analysis. Veg Hist Archaeobotany 22:71-82. https://doi.org/10.1007/s00334-0110341-z

Shillito L-M, Matthews W, Almond MJ, Bull ID (2011) The microstratigraphy of middens: capturing daily routine in rubbish at Neolithic Catalhöyük, Turkey. Antiquity 85:1024-1038. https://doi. org/10.1017/S0003598X00068460

Sofaer J (2015) Clay in the age of bronze. Essays in the archaeology of prehistoric creativity. Cambridge University Press, New York, US

Sørensen MLS (2010) with contributions by Beck, J-H., KulcsárnéBerzsényi, B., Kristiansen, K., Mühlenbock, C., Prescott, C. and Vicze, M. 2010. Households. In: Earle T and Kristiansen K (Eds.) Organizing Bronze Age Societies. The Mediterranean, Central Europe \& Scandinavia Compared. Cambridge, Cambridge University Press. 122-154

Sørensen MLS, Vicze M (2013) Locating household activities on a bronze age tell. In: Madella M, Kovács G, Kulcsárné-Berzsényi B, Briz i Godino I (eds) The archaeology of household. Oxbow Books, Oxford, pp 159-178

Sørensen MLS, Vicze M, Sofaer J (in press) Paradigm shift? Bronze Age Tell Archaeology after 1989. Reflections from the SzázhalombattaFöldvár Excavation Project

Starnini E, Szakmány G, Madella M (2007) Archaeometry of the first pottery production in the Carpathian Basin: results from two years of research, In: D’Amico C (Ed.), Atti Del IV Congresso Nazionale Aiar. Pisa, 1-3 febbraio 2006. Pátron Editore, Bologna, 401-411

Stika H-P, Heiss AG (2012) Archäobotanische Untersuchungen am bronzezeitlichen Tell von Százhalombatta-Földvár an der Donau in Ungarn. Offa 69/70, 2012/13, 411-427

Stika H-P, Heiss AG (2013) Seeds from the fire: Charred plant remains from Kristian Kristiansen's excavbations in Sweden, Denmark, Hungary and Sicily. In: Bergebranbt S, Sabatini S (eds) Counterpoint: essays in archaeology and heritage studies. BAR International Series 2508, Oxford, UK, 77-86 
Stoops G (2003) Guidelines for analysis and description of soil regolith and thin section. Soil Science Society of America Inc. Madison, Wisconsin, USA

Tomber R, Cartwright C, Gupta S (2011) Rice temper: technological solutions and source identification in the Indian Ocean. J Archaeol Sci 38(2):360-366

Varga A (2000) Coring results at Százhalombatta -Földvár. In: Poroszlai I - Vicze M (Eds.), SAX - Százhalombatta Archaeological Expedition Annual Report 1. Field Season 1998. Százhalombatta. $75-81$

Vicze M (2005) Excavation methods and some preliminary results of the SAX Project. In: Poroszlai I - Vicze M (Eds.), SAX Százhalombatta Archaeological Expedition Report 1. Field Season 2000-2003. Százhalombatta. 65-87

Vicze M (2013) Middle Bronze Age Households at SzázhalombattaFöldvár. In: Anders A, Kulcsár G, Kalla G, Kiss V V, Szabó G (Eds.) Moments in time. Papers presented to Pál Raczky on his 60th birthday. Prehistoric Studies I. Prehistoric Society, Eötvös Loránd University, L'Harmattan Budapest 757-769

Vicze M, Sofaer J, Sørensen MLS (2014) Glimpsing social organisation evidence from the Bronze Age tell at Százhalombatta-Földvár/ A társadalmi szerkezet régészeti lenyomata - Adatok a százhalombattai bronzkori tellről. Hungarian Archaeology EJournal - 2014 Summer

Vicze M, Sørensen MLS, Sofaer J (2017) Advances in tell researchmethodological reflections on the SAX Project In: Kulcsár G V, Szabó G with Kiss V, Váczi G (Eds.) State of the Hungarian Bronze Age Research. Proceedings of the conference held between 17th and 18th of December 2014. Ösrégészeti Tanulmányok / Prehistoric Studies II, Budapest 2017. 487-495

Vretemark M (2011) Subsistence strategies. In: Timothy E, Kristiansen K (Eds.), Organising Bronze Age Societies. The Mediterranean, Central Europe and Scandinavia compared. Cambridge University Press, Cambridge, UK, 155-184

Vrydaghs L, Devos Y (2018) Visibility, preservation and colour: a descriptive system for the study of opal phytoliths in (archaeological) soil and sediment thin section. Environ Archaeol 25(2):170-177. https://doi.org/10.1080/14614103.2018.1501867

Vrydaghs L, Devos Y, Pető Á (2017) Opal phytoliths. In: Nicosia C and Stoops G (Eds.), Archaeological soil and sediment micromorphology. Wiley Blackwell, Oxford, UK, 155-163

Publisher's note Springer Nature remains neutral with regard to jurisdictional claims in published maps and institutional affiliations. 